\title{
Structural and Functional Neural Correlates of Anorexia Nervosa
}

\author{
Anoreksiya Nervozanın Sinir Sistemindeki \\ Yapisal ve Işlevsel Etkileri \\ Deniz Atalayer
}

\begin{abstract}
Öz
Sinirbiliminden son on yıl içinde elde edilen bulgular, psikiyatrik hastalıkların algılanı̧ biçimiyle ilgili anlayışımızı şekillendirdi. Psikiyatrik bozuklukları açıklamada, psikolojik ve sosyokültürel faktörlere dayanan daha geleneksel teorilere ek olarak, genetik ve nörolojik bileşenleri de içeren çok yönlü bir etyolojiyi destekleyen kanıtlar her geçen gün artmaktadır. Kendini aç bırakma ve aşııı derecede düşük vücut ağırlı̆ı ile tanımlanan ve ölümcül olma riski yüksek bir psikiyatrik bozukluk olan anoreksiya nervoza, bu bulgular ışığında, bir beyin bozukluğu olarak sınıflandırılabilir. Birbirinden farklı sonuçlar mevcut olmakla birlikte, anoreksiya nervoza hastalarının beyinlerindeki yapısal ve nörokimyasal değişiklik ve anomalileri ve bunların işlevsel önemi ve bilişsel sonuçlarını araştıran birçok çalışma bulunmaktadır. Bu derlemenin amacı, anoreksiya nervozada saptanan anomali ve değişiklikleri ve bunları hedef alan birtakım tedavi yaklaşımları ile ilgili güncel literatürü bir araya getirmektir.
\end{abstract}

Anahtar sözcükler: Anorexia nervosa, beyin, sinirsel, yapısal, işlevsel.

\begin{abstract}
The findings from neuroscience have shaped our understanding in the past decade regarding the way we perceive psychiatric illness. In addition to the more conventional theories that are based solely on the psychological and sociocultural factors to explain psychiatric disorders, there is growing evidence supporting a multifactorial etiology with genetic and neurological components. Anorexia nervosa, a life-threatening psychiatric disorder with relentless restrictive eating resulting in extremely low body weight, is one such illness that may be categorized as a brain disorder based on the recent findings. Although inconsistencies exist, several studies investigated the structural and the neurochemical alterations in the brain as well as the functional significance and the cognitive manifestations of these abnormalities in anorexia nervosa patient. This review aims to summarize the current literature on the neural aberrations and several treatment approaches targeting these abnormalities in anorexia nervosa.

Key words: Anorexia nervosa, neural, neurological, structural, functional.
\end{abstract}

THE MORBID question of why without being suicidal, people would starve themselves to the point of death has led the researchers and clinicians for the quest of an effective answer to help persons with anorexia nervosa (AN), a psychiatric disorder with pathology related to eating behavior. Technological advances in the 21 st century al- 
lowed investigators to use more refined methods to examine the neurobiological and the physiological substrates potentially underlying the pathogenesis related to psychiatric disorders have shaped our understanding regarding how we perceive mental illnesses. In addition to the more conventional theories that are based solely on the psychological and sociocultural factors to explain psychiatric disorders, there is growing evidence supporting a multifactorial etiology with genetic and neurological components and the literature on the brain-related impairments in patients suffering from AN has grown in the past decade.

Neuroimaging methods such as a positron emission tomography (PET), singlephoton emission computed tomography (SPECT), diffusion weighted imaging (DWI), and magnetic resonance imaging (MRI), and functional MRI (fMRI) are being used to assess the alterations in neural regions and the related symptoms in AN patients compared to the healthy population (Güney and Kuruoğlu 2007). Although inconsistencies exist, common findings from studies employing these methodologies have elucidated a neuropathology related to AN. Specifically, brain abnormalities including global and regional volume reductions and neural response aberrations, as well as differences in the structural and functional neural circuitry in regions associated with executive function, reward evaluation, visuospatial abilities, interoception, and behavioral inhibition (Casiero and Frishman 2006, Teng 2011, Warren 2011, Lipsman et al. 2015, Collantoni et al 2016) have all been reported in patients with AN. Although neuroimaging is not being utilized as a diagnostic tool, several groups also suggested therapeutic interventions targeting the brain such as deep brain stimulation (DBS), transcranial magnetic stimulation (TMS) as well as pharmaceutical agents targeting the proposed aberrant neural signaling (Lipsman et al. 2013).

Currently, assumed effective therapies exist for $\mathrm{AN}$ however, remission rates are not ideal (Hay 2013, Fairburn et al. 2015, Turner et al. 2015). Thus, in the quest to develop novel interventions, attention to the structural and the functional neural alterations associated with AN may lead to the development of more effective novel interventions for AN. In this review, general contributions of studies analyzing the structural and functional (global and regional) alterations in the brain as well as the neural functional connectivity in patients with $\mathrm{AN}$ are summarized.

\section{Definition of Anorexia Nervosa}

$\mathrm{AN}$ is a life-threatening psychiatric disorder of unknown etiology involving heterogeneous environmental and genetic factors and has a complex psychopathology and pathophysiology. AN persons exhibit an obsessive concern about becoming overweight and excessive dietary restraint (restrictive subtype) which may also present in conjunction with binge eating and subsequent purging (binge-eating/purge subtype) or other forms of compensatory behavior (e.g., laxative misuse, excessive exercise) to avoid weight gain despite being severely underweight. It affects about $0.9 \%$ of women and $0.3 \%$ of men (Hudson et al. 2007) and has the highest mortality rate of any mental disorder (Sullivan 1995). Most recent diagnostic criteria according to the fifth edition of the Diagnostic and Statistical Manual of Mental Disorders (DSM-5) includes extremely low body weight, obsessive fear of gaining weight or becoming fat, relentless pursuit of thinness, distorted body image (a skewed perception of body shape) and psychological suffering and anxiety related to the changes in body weight (APA 2013). 


\section{Neuropsychological Processes and Symptomatology}

Patients with AN, despite being dangerously thin and having a cognitive preoccupation with food, are faithfully obsessed with restricting their food intake to lose weight and maintain an extreme level of thinness, which may be stemming from a distorted body image. Distorted body image, a puzzling symptom of AN, is defined by thinking one is fat despite being cachectic that displays itself as a significant influence of weight and shape on one's self-evaluation and was suggested to be partially caused by a cognitive bias in AN (Williamson 2004). Specifically, weak central coherence -a bias towards processing details rather than the whole picture i.e. a processing preference for local (detail-focused) over global ("bigger picture") information, has been proposed in AN patient (Lopez et al. 2008b, Southgate et al. 2008). Perfectionism, an overcontrolling personality trait (i.e., dietary restraint), is implicated in AN symptomatology (Dawe and Loxton 2004, Bardone-Cone et al. 2007). This agrees with the reports for the other end of the spectrum related to the eating-related disorders, that suggest an association such as between the undercontrolling personality trait i.e. impulsivity and lack of control in eating (i.e. bulimia nervosa, binge eating disorder, obesity) (Slof-Op't Landt et al. 2013, Boone et al. 2014). Harm avoidance, a measure of anxiety and strong behavioral inhibition, that is defined as the tendency of responding intensely to a previously established aversive stimulus, passively avoiding punishment, and being slow to adapt changes (Cloninger et al. 1998), has been shown to be elevated in AN. Harm avoidance has been shown to negatively associate with positive emotionality, selfesteem (Cloninger et al. 1998), and mood disorders (Young et al. 1995), and was reported to also persist after recovery in persons with AN (Klump et al. 2004, Cassin and von Ranson 2005, Wagner et al. 2006).

Collectively, the results from numerous studies with multidisciplinary approach seem to imply that impairments in one or multiple cognitive components may underlie AN symptomatology (Renwick et al. 2015, Tenconi et al. 2016). These include but not limited to deficits in visuospatial abilities (Szmukler et al. 1992, Kingston et al. 1996, Favaro et al. 2012), memory (Green et al. 1996, Seed et al. 2000, Nikendei et al. 2011), reward-related cognitive processes (Goethals et al. 2007, Wagner et al. 2007), executive functions, i.e. set-shifting, that is defined as rigid response to criteria-change, elevated perseverative responses, and switching errors (Tchanturia et al. 2004, 2012, Holliday et al. 2005, Steinglass et al. 2006, Roberts et al. 2007, 2010, Zastrow et al. 2009, Sato et al. 2013, Guillaume et al. 2015, Collantoni et al. 2016), as well as social cognition (Perçinel et al 2014). Studies also showed that only partial remission in these cognitive alterations to have been achieved following weight recovery (Tchanturia et al. 2004, Roberts et al. 2010, Kanakam et al. 2013). Specifically, abnormal neuropsychological tests (verbal abilities, cognitive efficiency, reading, mathematics, and long-term verbal memory) after 6 years of the initial diagnosis (Chui et al. 2008) and impaired cognitive flexibility after 3.6 years of recovery (Friedrich et al. 2012) have been reported. A study in a group of acute and recovered persons with $\mathrm{AN}$ and bulimia nervosa (BN), although reported a lack of correlation between BMI and cognitive flexibility measured by setshifting, found an association of cognitive flexibility with the duration and severity of illness (Roberts et al. 2010). Lastly, the same study and others (Holliday et al. 2005, Roberts et al. 2010) also reported that poorer cognitive flexibility (set-shifting) was found in healthy sisters of AN patients implying a possible genetic component. These 
findings seem to suggest that aberrations in cognitive processes may potentially be considered as a transdiagnostic endophenotype to develop AN (Lopez et al. 2008a, Tchanturia et al. 2012) rather than a mere consequence of malnutrition and extreme negative energy balance in AN individuals.

\section{Structural Neural Alterations}

Several longitudinal studies with small sample sizes and short-term follow-ups exist examining structural alterations in AN patients using brain imaging methods. The majority of studies used an analysis technique called the voxel-based morphometry (VBM), which compared the intensity differences in images acquired via MRI with voxel-based probability. Studies also employed DWI, a method assessing the microstructural white matter (WM) organization. Common findings from several metaanalyses collectively looking at these studies indicate volumetric alterations in the brain in acute AN patients such as reductions in total and regional gray matter (GM), WM, and cerebrospinal fluid (Van den Eynde et al. 2012, Titova et al. 2013, Seitz et al. 2014). Among these alterations, although GM reductions have been commonly found, inconsistencies exist regarding the alterations in WM and CSF volumetrics in AN. Moreover, several studies reported recovery of these alterations with remission suggesting state-related factors underlying these aberrations in AN (King et al. 2015, see for details Seitz et al. 2014).

\section{Gray Matter Volume}

Studies consistently reported gray matter volume (GMV) decreases in AN patients (Castro-Fornieles et al. 2009, Suchan et al. 2010, van Gaudio et al. 2011, Joos et al. 2010, 2011, Friedrich et al 2012, Via et al 2014, Opstal et al. 2015, Bomba et al. 2015). Majority of these studies showed that this effect occurs on a weight-dependent fashion (Bomba et al. 2013) thus, although it is not clear whether they normalize completely, total GMV reductions showed remission at the weight recovery follow-up (Kingston et al. 1996, Katzman et al. 1997, Lambe et al. 1997, Swayze et al. 2003, Wagner et al. 2006, Muhlau et al. 2007, Castro-Fornieles et al. 2009, Gaudio et al. 2011, Friedrich et al. 2012, Van den Eynde et al. 2012, Bomba et al. 2015).

Regional GM reductions have also been examined. Volumetric alterations in the corticolimbostriatal neurocircuitry, a system involved in reward processing, mood, motivation, and decision making, have been implicated to underlie the impaired cognitive and behavioral abnormalities in AN (Frank et al. 2005, Friederich et al. 2006, 2012, Wagner et al. 2007, Kaye et al. 2009, Zastrow et al. 2009, Keating et al. 2012, Roberts et al. 2010, Bomba et al. 2015). Kaye et al. (2005, 2009) describes two parts of this system (ventral and dorsal) of which dysfunctions could be related to AN pathology. The ventral (limbic) part of this neurocircuit is composed of areas (i.e. ventral striatum including nucleus accumbens (NAc), ventral anterior cingulate cortex (ACC), orbitofrontal cortex (OFC), amygdala, insula) that are collectively involved in recognizing the emotional significance of the stimuli and in creating an effective response to them (Rolls et al. 2010). The dorsal (cognitive) part of the neurocircuit is composed of areas (hippocampus, dorsal ACC, dorsal striatum, dorsolateral prefrontal cortex (DLPFC), parietal cortex, and other cortical regions) that are implicated in modulating selective attention, planning an effortful regulation of affective states (Toni and 
Passingham 1999, Baldo and Kelley 2007, Robinson et al. 2009, Ghahremani 2012, Robbins et al. 2012, Schultz 2012, Jimura et al. 2013, Bar et al. 2015, Volkow and Baler 2015). Volumetric GM reductions in the ventral part i.e. ACC, frontal operculum, temporal cortex (i.e. superior temporal gyrus and temporoparietal junction), occipitotemporal cortex, parietal cortex (i.e. precuneus and inferior parietal lobe), and supplementary motor area (SMA), have been consistently reported in AN patients (Castro-Fornieles et al. 2009, Joos et al. 2010, Suchan et al. 2010, Gaudio et al. 2011, Friederich et al. 2012, van Opstal et al. 2015). The studies with SPECT, have shown hypoperfusion in the bilateral ACC in adults with AN (Naruo et al. 2001, Kojima et al. 2005, Takano et al. 2001) and in weight restored AN (Kojima et al. 2005). Significant GMV reductions in dorsal striatum (i.e. putamen), thalamus, midbrain regions, amygdala and hippocampus/parahippocampus in AN have been reported by several groups (Husain et al. 1992, Neumarker et al. 2000, Giordano et al. 2001, Kojima et al 2005, Connan et al. 2006, Brooks et al. 2011, Friederich et al. 2012, van den Eynde et al. 2012, Fonville et al. 2014, Bomba et al. 2015, Sanders et al. 2015). Findings regarding the regional GMV reductions in hippocampus however, have not been consistent (Giordano et al. 2001, Connan et al. 2006, Chui et al. 2008, Brooks et al. 2011, Mainz et al. 2012) as some studies also reported no difference in this region (Castro-Fornieles et al. 2009, Joos et al. 2010, Gaudio et al. 2011).

Additionally, cortical thickness has been recently suggested to be a better predictor for structural alterations than volume. It has been previously shown that GMV is, both globally and regionally, a function of cortical thickness and surface area, which are independent and heritable (Panizzon et al. 2009, Winkler et al. 2009). In patients with AN, Wagner and colleagues (Bar et al. 2015) recently showed significantly lower cortical thickness in the frontocingulate and parietal regions. Moreover, a relationship between BMI and the cortical thickness in the left superior parietal/occipital cortex and left post central cortex was reported in AN patients (vs. healthy controls) (Lavagnino et al. 2016).

\section{White Matter Volume}

White matter volume (WMV) related results in AN have been mostly controversial. Reductions in total WMV (Katzman et al. 1997, Swayze et al. 2003, Bomba et al. 2015) that may persist after weight recovery (1-year follow-up) (Bomba et al. 2015) have been shown using MRI. However, no change in WMV has also reported (CastroFornieles et al. 2009, Joos et al. 2010, Suchan et al. 2010, Friedrich et al. 2012) in AN patients, along with no difference between recovered AN patients and healthy controls (Wagner et al. 2006, Muhlau et al. 2007).

Studies using DWI, a method assessing the microstructural WM organization as an indicator of fiber quality potentially providing estimates of number of neural connections, may seem to partially explain the inconsistent reports on WMV alterations in AN. DWI is based on the analysis of the brain's water diffusion, and allows the evaluation of even the subtle microstructural WM pathology reflecting de-myelination and/or WM integrity which may not be detected with a volumetric approach such as VBM (Le Bihan et al. 2001). Findings from such reports indicate abnormalities in WM micro $\neg$ structure in adult acute (Kazlouski et al. 2011, Frieling et al. 2012, Via et al. 2014) and recovered (Yau et al. 2013, Hayes et al. 2015) AN patients as well as AN 
adolescents (Frank et al. 2013). Specifically, greater left parieto-occipital cortices and lower thalamus connectivity (Hayes et al. 2015) and significant microstructural reductions in superior lon gitudinal fasciculus (a major association fiber, connecting frontal to parietotemporal and occipital areas), ACC, and fornix -a fiber bundle between hippocampus, mammillary bodies and thalamus, reported in AN (Kazlouski et al. 2011, Via et al. 2014, Hayes et al. 2015,). This agreed with previous studies reporting microstructural abnormalities in bilateral fimbria-fornix, superior and inferior frontooccipital fasciculi, and posterior cingulum (a bundle between cingulate cortex and hippocampal formation) (Kazlouski et al. 2011, Frank et al. 2013), and right corpus callosum, the largest bundle connecting the cerebral hemispheres, and the right superior longitudinal fasciculus (Nagahara et al. 2014) in AN. Moreover, a recent study showed greater WM connections and lower WM integrity in fibers projecting from insula to ventral striatum and OFC, which was predicted by illness duration (Shott et al. 2016). Thus, although inconsistencies exits, these findings collectively support a role for WM pathology of specific neural circuits in AN.

\section{Cerebrospinal Fluid}

Several studies reported increased cerebrospinal fluid (CSF) volume in AN patients that normalizes after recovery in a weight dependent manner (Castro-Fornieles et al. 2009, Joos et al. 2010, Bomba et al. 2015). Consistent with this, earlier studies also found enlarged ventricles (Artmann et al. 1985, Golden et al. 1996, Kingston et al. 1996, Swayze 1996). On the other hand, reports of no change in CSF also do exist (Wagner et al. 2006, Suchan et al. 2010, Friedrich et al. 2012). Interestingly however, in one of such reports, the CSF levels of the control participants were almost two times higher (753 [unit not reported]) (Suchan et al. 2010) than the control participants in the studies showing the CSF increase $\left(221 \mathrm{~cm}^{3}, 163 \mathrm{~cm}^{3}, 253 \mathrm{~cm}^{3}, 186\right.$ [unit not specified], 313 ml) (Bomba et al. 2015, Castro-Fornieles et al. 2009, Friedrich et al. 2012, Joos et al. 2010, Wagner et al. 2006, respectively). It is possible that there may be a ceiling effect of the high baseline in the group of participants in the study by Suchan et al. (2010). Thus, collectively a trend towards an increase in CSF in AN patients (vs. healthy controls) seems to be apparent.

\section{Functional Alterations}

Although the functional relevance of regional structural abnormalities in $\mathrm{AN}$ is largely unknown, studies have explored the neural processes underlying visuospatial ability (Palazidou et al. 1990, Jones et al. 1991, Szmukler et al. 1992, Kingston et al. 1996, Favaro et al. 2012), attention and memory (Jones et al. 1991, Szmukler et al. 1992, Green et al. 1996, Kingston et al. 1996, Seed et al. 2000, Nikendei et al. 2011), reward processing, emotional regulation (Jänsch et al. 2009, Joos et al. 2009, Cowdrey et al. 2012), social cognition (McAdams and Krawczyk 2011), cognitive flexibility (Uher et al. 2003, Garret et al 2014) and perfectionism (Tchanchuria et al. 2004, Roberts et al. 2007, Zastrow et al. 2009, Sato et al. 2013) in acute and recovered AN patients. These studies examining the neurofunctional aspects of $\mathrm{AN}$ indicate aberrations in activity within the cortico-limbo-striatal system, including but not limited to DLPFC, ACC, OFC, insula, ventral and dorsal striatum, and the thalamus (Friederich et al. 2006, Wagner et al. 2007, 2008, Zastrow et al. 2009, Frank et al. 2012, Kaye et al. 2013). 


\section{Cortical Structures}

\section{Anterior Cingulate Cortex}

In line with the reductions in regional blood flow and volume in ACC (Kojima et al. 2005), functional alterations in the ACC in both the acute and weight-restored AN patients have been reported (Frank et al. 2002, Uher et al. 2003, Pieters et al. 2007, Zastrow et al. 2009). Hypoactivation in the ACC in AN compared to healthy persons has been reported during a Stroop test -a task requiring response flexibility (Ferro et al. 2005) via SPECT and during a target detection task (using geometric shapes) measuring cognitive shifts in AN which persisted after recovery (via fMRI) (Zastrow et al. 2009). Along with reduced ventral and dorsal striatum activity, ACC hypoactivation (fMRI) was also shown in response to sucrose vs. water administration in AN patients (vs. healthy controls) (Wagner et al. 2008). Conversely, several fMRI studies reported abnormally elevated ACC activity AN patients, in response to food stimuli in (Uher et al. 2003, Sanders et al. 2015), and in a Wisconsin Card Sorting Test (Sato et al. 2013), a frequently used task for measuring cognitive flexibility and problem-solving ability (Stuss et al. 2000). The inconsistency may be partially explained by the multimodal and heterogeneous feature of ACC with potential heterogeneous functions (e.g. emotional evaluation, response selection, processing hedonic properties of food, body image perception etc.) (Vogt et al. 1995, Carter et al. 1998, Bush et al. 2002, Kjaer et al. 2002, de Araujo and Rolls 2004, Margulies et al. 2007).

Ventral ACC has been predominantly reported to decrease in both the acute and weight-restored AN patients (Pieters et al. 2007 [via EEG], Sato et al. 2013, Zastrow et al. 2009 [both via $\mathrm{fMRI}$ ]). It is involved in motivational and emotional aspects of reward processing (Delgado et al. 2000), and mostly projects to OFC and amygdala (Schultz et al. 2000) together comprising the ventral (limbic) pathway of reward processing (Kaye et al. 2009, 2013). On the other hand, the dorsal ACC, which, to a greater extent is involved in cognitive processes such as conflict detection and complex information processing (Bush et al. 2000), was shown to have increased activity (via fMRI) in AN (Uher et al. 2003, Bar et al. 2015). It is part of the proposed dorsal (cognitive) pathway (Kaye et al. 2009, 2013) and also has bilateral projections with DLPFC (Sallet et al. 2011), an area specifically involved in impulse control and cognitive inhibition (Diamond 1990, Chikama et al. 1997), task switching based on the information at hand (Kerns et al. 2004, Hikosaka and Isoda 2010). Activity in DLPFC was also found to show weight independent (Brooks et al. 2011) increases in AN patients (Zastrow et al. 2009, Frank et al. 2012, Castellini et al. 2013, Sato et al. 2013, Garret et al. 2014). Thus, collectively it is possible to postulate that in AN patients, decreased ventral ACC activity may be involved in processes related to decreased reward-salience assessment whereas increased dorsal ACC may be speculated to be involved in the processing of greater behavioral control over eating. In line with this, a recent fMRI study by Walsh and colleagues (Foerde et al. 2015) reported higher activity in dorsal striatum (but not ventral striatum) in AN (vs. healthy controls) during food choice. However, results from the same study did not show higher activity in dorsal striatum during the earlier taste or health rating phases of the study. Thus, it appears that higher dorsal striatum activity correlates with the food-related decision making rather than the assessment of the interoceptive sensory properties of the tastants. Another interpretation would be that the increased dorsal striatum activity may be a compensation mechanism for a 
deficit in interoception as the recognition of emotional states of the self that was shown to be impaired in these patients (Matsumoto et al. 2006) which may be supported by the reduced activity in both ventral and dorsal striatum in response to sucrose that has been shown previously (Wagner et al. 2008).

\section{Insula and Orbitofrontal Cortex}

The insular cortex, another region of the corticolimbostriatal pathway, is involved in taste sensation, physical properties, and the incentive value of the food (Small et al. 2001) and its sub-optimal functioning has been proposed to be considered a predisposing risk factor associated with AN (Nunn et al. 2008). It is the primary gustatory cortex (Ogawa et al. 1994) and interconnects the prefrontal cortical areas (a large group of regions involved in executive function) and dorsal striatum directly to the ventral striatum (Kaye et al. 2009, Craig 2010), a region is important for dopamine-mediated reward learning (O'Doherty et al. 2003, Hinton et al. 2004).

In healthy individuals increased insula and OFC activity have consistently been shown at a fasting state, compared to the states of satiety (Haase et al. 2009, Vocks et al. 2011). Activity in insula was shown in response to the ingestion following a fasting state however was failed to be found in AN patients (Vocks et al. 2011). Another study however, reported increased insula activity in response to sucrose versus water ingestion in AN persons compared to the healthy persons as well as obese individuals (Frank et al. 2012). It is possible that $A N$ individuals have decreased baseline activity in insula however, in response to ingestion, activity may be higher these patients. In line with this, increased insula activity in AN is reported in response to a body image task (Fladung et al. 2010, Friederich et al. 2010, Mohr et al. 2010) and a cognitive flexibility task (set shifting) (Sato et al. 2013) as well as high calorie food pictures (Kim et al. 2012). A study reported no insula activation in the AN patients have also been reported to high and low calorie food pictures vs. non-food pictures (Sanders et al. 2015). It is possible that the opposite results of increased (Kim et al. 2012) vs. no activity (Sanders et al. 2015) in insula may stem from the caloric content of the food used in the cues, as using both high and low calorie food pictures (Sanders et al. 2015) may have blunted the results and that AN persons may have an abnormal activity in response to high calorie foods specifically (Kim et al. 2012). In recovered AN individuals, insular activity did not correlate with pleasantness ratings for sucrose while it did for healthy persons (Wagner et al. 2008) and decreased insula in response to repeated sucrose and water ingestion (Wagner et al. 2008), as well as during food anticipation (Oberndorfer et al. 2013) have been shown, which may indicate that insula activity to be dependent on the illness status.

Moreover, Kullmann et al. (2014) showed increased connectivity in AN OFC and insula (Kullmann et al. 2014) and increased OFC responsivity to high calorie food (vs. non-food) pictures reported in AN (Frank et al. 2012). Insula also interconnects the prefrontal cortical areas and dorsal striatum directly to OFC (Kaye et al. 2009), an area that fine-tunes striatal dopamine activation and the motivation to approach food (Rolls et al. 2010). Majority of studies agree that OFC has a unique role in the eating behavior related decision-making processes (Kringelbach 2004), and considered the secondary olfactory and gustatory cortices after insula (Pritchard et al. 2007, Shepherd 2007, Simmons et al. 2007). Moreover, humans with ventromediofrontal cortex (medial OFC + adjacent ventral region of medial PFC) damage were shown to have deficits in adap- 
tation of a new economical strategy from a prepotent disadvantageous item to the newly advantageous one (Fellows 2007). This may be considered as the function of cognitive flexibility (set-shifting) which was reported to be poor and heritable in AN patients (Holliday et al. 2005, Roberts et al. 2010). Thus, it is possible that AN patients may possess a taste-related reward salience fails to be processed in the insula which reflects in the OFC activity regarding the taste-related decision making. This appears to be supported by the findings showing reduced insula activity in response to the sensory information of taste (Frank et al. 2012, Sanders et al. 2015), and reduced insula projections to the OFC, ACC, amygdala and the ventral striatum shown via DWI (Shott et al. 2016) in AN population. These might comprise the mechanism that underlie the ventral pathway aberrations shown in AN and may suggest lower sensoryhedonic experiences for the motivational components of food reward in AN (Kaye et al. 2009).

To summarize some of these findings, a recent report by Kaye and colleagues (Wierenga et al. 2015) may be of importance, an increased activity was shown in reward salience neural pathway (ventral striatum, dorsal caudate, ACC, insula during processing of immediate non-food reward in healthy individuals when fasted whereas satiety was shown to increase the activity in the cognitive control circuitry (prefrontal cortex). However, AN persons in remission failed to show reward circuitry activity when hungry and showed elevated activity in cognitive control circuitry regardless of the energy balance (Wierenga et al. 2015). This decreased sensitivity to the motivational drive of hunger was speculated to be the mechanism underlying the ability of AN patients to restrict food when emaciated (Wierenga et al. 2015) which cannot be explained by a neural deficit in the primitive neural pathways of the energy homeostasis (i.e. hypothalamus). This was supported by the no differences found between AN patients vs. controls in response to a glucose load in hypothalamic activity (via fMRI) and volume (via VBM) (van Opstal et al. 2015).

\section{Occipito-Parietal Regions}

Regarding the most puzzling symptom of AN, the distorted body image, several studies examining the structural WM connectivity indicated a role of fronto occipito-parietal regions (Via et al. 2014, Hayes et al. 2015). Specifically, decreased activity in precuneus, an area involved in visuo-spatial imagery, episodic memory retrieval and self-processing operation (Cavanna et al. 2006), and parietal lobe in AN patients have been shown in response to the images of one's own body (Vocks et al. 2010), to the line drawings of female body shapes of different body weight (Uher et al. 2005), to the morphed images of subjects' own bodies (Wagner et al. 2003, Mohr et al. 2010). Moreover, decreased activity in the inferior parietal lobule (IPL), a region related to tool use judgment and manipulation, visual working memory (Ishibashi et al. 2011), was reported in response to visual food stimuli in AN (Uher et al. 2003, Brooks et al. 2011) and in AN and BN combined (Uher et al. 2004). Similarly, abnormal spatiotemporal activity measured by $\mathrm{fMRI}$ in AN and people with body dysmorphic disorder for configural/holistic visual information was reported ( $\mathrm{Li}$ et al. 2015). These reductions in neural activity in these regions are in line with the reductions in GMV in IPL and precuneus (CastroFornieles et al. 2009, Joos et al. 2010, 2011, Gaudio et al. 2011) together may be reflecting a general failure to represent and evaluate one's own body in a realistic fashion.

Of note, a possible general deficit in sensory (gustatory, olfactory, visual perception) information detection or integration was negated by studies showing that AN persons 
were correct in estimating the width of various objects (Bowden et al. 1989, GoldzakKunik et al. 2012). It is possible that the visual sensory deficit may be specific to human body in AN. This was indicated by both decreased GMV (Suchan et al. 2010) and functional reductions in response to images of human bodies or body parts in AN patients vs. healthy controls (Wagner et al. 2003, Uher et al. 2005, Suchan et al. 2015) as well as ingestion (Vocks et al. 2011) in extrastriate body area (EBA), an area involved in the perception of whole bodies and body parts of the human body (Downing et al. 2001, Urgesi et al. 2004). Moreover, reduced functional connectivity between fusiform gyrus (a face recognition area) and EBA has been shown in AN (Suchan et al. 2013). These functional reductions were found to increased following treatment (Vocks et al. 2010). Adding to this, interestingly, although they have biased self-perception AN patients were not different than the healthy controls in their responses to 'Which do you think others consider the most beautiful?' question (Goldzak-Kunik et al. 2012). This may be indicative of a major perception bias towards the 'self. Collectively, information processing deficit leading the skewed perspective of 'ideal body' in AN may be specific to visual stimuli related to human body which also occurs specifically when applied to the 'self.

\section{Subcortical Structures}

\section{Amygdala}

Goldzak-Kunik and colleagues (2012) interpreted the mechanism underlying the distorted body image symptom as affective-cognitive, rather than a perceptual, distortion in AN. The hypothesis of a general cognitive-affective deficit in AN may be supported by the reported impairments in emotion processing (Jänsch et al. 2009, Joos et al. 2009), attention bias towards negative facial expression (Cserjési et al. 2011). Furthermore, undifferentiated neural responsivity in amygdala (a key fear/emotion processing area) and fusiform gyrus, when exposed to fearful or happy facial expressions have also been reported in recovered AN patients (Cowdrey et al. 2012). On the other hand, fear processing has been shown to differ in AN patients related to food. Specifically, it has been shown that food cues may predict fear for individuals with AN (Connan et al. 2003). Adding to this, a meta-analysis of fMRI studies showed that in response to visual food cues, patients with AN (vs. healthy controls) had stronger activity in regions of fear processing, especially in the amygdala (Zhu et al. 2012). The amygdalar activity is known to have inhibitory projections to the brainstem, i.e. the lateral hypothalamus (Swanson and Petrovich 1998), part of the hypothalamic regions involved in satiety (Teitelbaum and Stellar 1964). Collectively, one may speculate that decreased limbic responses to food cues and a co-morbid occurrence of a deficit in reward salience perception together may result in a failure to process and identify the salient food stimuli and thus play a role in the suppression of food intake in AN.

\section{Hypothalamic Network}

It has been generally accepted that the restricted eating behavior in $\mathrm{AN}$ does not stem from an impairment in the homeostatic pathways (i.e. hypothalamus, brainstem) signaling hunger, however consequential homeostatic alterations have been reported in AN. Starvation and extreme low body weight have both been show to associate with an increase in orexigenic peptides and a decrease in anorexigenic peptides in AN patients (Prince et al. 2009, Monteleone and Maj 2013, Smitka et al. 2013), possibly as a com- 
pensatory mechanism to counteract the negative energy balance in these patients (Berthoud 2002). Specifically, increased plasma levels of ghrelin, a hormone signaling hunger (Ariyasu et al. 2001), and impaired ghrelin response to meal (Prince et al. 2009, Terashi et al. 2011) and low levels of leptin (Monteleone et al. 2000, Dostalova et al. 2005), a hormone secreted in proportion to the body fat and involved in regulating energy homeostasis through stimulating hypothalamic anorexigenic neurons and inhibiting orexigenic neurons (Blundell et al. 2001), have both been shown. Decreases in leptin also inhibit the activity of the hypothalamic-pituitary-adrenal stress (HPA) axis, the key neural pathway for stress, (Roubos et al. 2012) and thus low leptin in AN may contribute to HPA axis hyperactivity. Supporting this, the patients with AN have been found (Kaye et al. 1987, Lo Sauro et al. 2008) to show increased corticotropin-releasing factor (CRF) and hyperactivity of the HPA axis, both of which are known to be the neural substrates of chronic stress (Bremner et al. 1997). The anorexic effects of the sympathetic stress response are well documented, (Veling et al. 2011, Petrovich, 2013) which may contribute AN pathology (Lawson et al. 2013). Moreover, fasting and negative energy balance are known stressors reducing brain serotonin levels (Haleem and Haider 1996) and affecting the HPA axis leading further stress (Gold et al. 1986). Thus, the anorectic effects of CRF may be involved in starvation and sustained negative energy balance in AN both of which might drive further HPA dysregulation driving further food restriction creating a vicious circle (Kaye et al. 2009).

\section{Alterations in the Functional Neural Connectivity}

While patterns of neural activation during certain cognitive tasks have been studied in $\mathrm{AN}$, the patterns of functional connectivity between brain regions remain relatively less explored. However, how the human brain produces cognition ultimately depends on the large-scale organization of the neural networks (Bressler and Menon 2010). These functional neural networks are examined via functional connectivity analyses that assess the simultaneous activity in the brain areas (connectomics) (Lichtman and Sanes, 2008) and the simultaneous activity of the brain areas with a particular seed region, i.e. psychophysiological interactions (PPI) (Friston et al. 1997) during a particular task or at resting state. Thus, the outputs from these analyses provide support for neural interactivity, or "crosstalk," between brain regions suggestive of a certain neural network underlying a status of interest such as cognitive processes, behaviors, traits, illness status etc. The resting state networks of functional connectivity via resting-state fMRI (rsfMRI) are also a target of interest for researchers as they indicate functional organization of the brain (Zhang and Raichle 2010). Studies showed differential functional connectivity of networks involved in visuospatial tasks (Suchan et al. 2013) and somatosensory processing at rest (Favaro et al. 2012) in AN patients (vs. healthy individuals). Abnormal functional connectivity of the thalamus with the DLPFC and anterior PFC (thalamo-frontal pathway) measured via rs- fMRI in AN was shown to associate with lower Stroop task performance and working memory (Biezonski et al. 2016). Another recent study using rs-fMRI showed alterations in large-scale neural networks and locally decreased con $\neg$ nectivity strength and increased path length in the posterior insula and thalamus in AN patients vs. healthy controls (Geisler et al. 2016). Moreover, altered microstructure of WM shown via DWI (a measure of bundle of fibers structurally connecting brain sites indicative of a functional connection), mentioned earlier in 
this review, also suggests an altered functional connectivity in AN patients. However, further research with connectivity analyses is needed to support these results.

\section{Neurochemical Alterations}

Neurotransmitter systems such as dopamine (DA), opioids, and serotonin (5-TH) are implicated in the regulation of appetitive/incentive (food "wanting") and pleasure/palatability (food "liking") motivational states of feeding which have separable neural substrates (Berridge 1996) and might critically contribute in taste perception and preference (Peciña and Smith 2010). Aberrations in the principle neurotransmitters involved in these neural pathways may result in the dysregulation of energy balance, appetite, and eating behavior as well as mood, and impulse control. Specifically, alterations in DA and 5-HT have been implicated in AN (Daw et al. 2002, Kaye et al. 2009).

Alterations in the dopaminergic system have been proposed to be responsible of a devalued reward and reduced food intake in AN (Kaye et al. 1999, 2009, Lawrence et al. 2003, Bergen et al. 2005, Friederich et al. 2006, Kaye 2008, Avena and Bocarsly 2012). Specifically, polymorphisms in DA receptor (D2DR) gene (Bergen et al. 2005) and reduced DA metabolite levels in the CSF in acute AN (Kaye et al. 1999), and increased DA receptor (D2/D3) binding (via PET) in the ventral striatum in recovered AN persons (Frank et al. 2005) have been reported. In healthy persons, it has been shown (via PET) that there is a negative correlation between harm avoidance and DA receptor (D2/D3) availability in regions related to cognition and locomotion (Kim et al. 2011). However, finding of no differences in DA receptor binding in acute (Broft et al. 2015) and recovered AN patients compared to healthy controls has also been reported (Bailer et al. 2013, Broft et al. 2015). Although there are inconsistent findings on the receptor binding, it appears that potential DA-related abnormalities are strongly supported by the majority of the studies.

Evidence shows abnormal functional activity of the 5-HT system in persons with AN during illness (Kaye 2008) and after recovery (Kaye et al. 2005, Bailer et al. 2007b, 2013) and in animals (Santana et al. 2004, Verhagen et al. 2009, Jean et al. 2012). Associations have been shown between AN symptomatology and polymorphisms in the gene coding for the 5-HT receptor and transporter (Gorwood et al. 2003, Brown et al. 2007, Martásková et al. 2009, Lee and Lin 2010, Calati et al. 2011, Collantoni et al. 2016, Tenconi et al. 2016) and between reduced food ingestion and increased 5-HT transmission (Steiger 2004). The functional significance of 5-HT in AN is yet to be elucidated however, few theories have been proposed. Serotonergic neurons were shown to be sensitive to aversiveness (Vicario 2013) which is one of the core symptoms of AN, characterized by a marked disgust sensitivity for food and the human body (Harvey et al. 2002). In PET studies exploring exaggerated binding potential of 5-HT 1A receptors but not 5-HT2A in acute AN (Bailer et al. 2007a) and following recovery (Bailer et al. 2005, 207b) have been reported. Moreover, along with DA (Frank et al. 2005), alterations in 5-HT (Bailer et al. 2005, 2007a) have been shown to be related to harm avoidance in AN (Bailer et al. 2013). Thus it is possible that 5-HT and DA interactions may be contributing to HA behaviors in AN. Moreover, using a novel approach with neurogenetics, Favaro and colleagues (Collantoni et al. 2016) reported that in during a task measuring inhibitory control, an executive function of behavioral adapta- 
tion while considering both internal demands and external contingencies, 5-HT transporter protein (5-HTTLPR) genotype significantly interacted with the functional connectivity (via rs-fMRI) of ventral attention network, however AN patients did not differ from the controls. Nevertheless, it would be beneficial to employ neurogenetic tools to elucidate the functional significance of the serotonergic disruptions in AN symptomatology as well as potential etiology in the further studies.

It has been suggested that endogenous opioid systems are elevated in patients with AN (Marrazzi et al. 1997, Monteleone et al. 2005) and gene polymorphisms of the delta-1 receptor has been linked to restricting-type AN (Brown et al. 2007). The link between opioids and exercise has been well documented (Sforzo 1989), and excessive exercise is a hallmark symptom of AN (APA 2013). Literature shows that exercise increases the serum concentrations of endocannabinoids which is involved in the exercise-induced alterations of mental status (e.g. runner's high, exercise-induced analgesia and sedation) (Dietrich and McDaniel 2004, Sparling et al. 2003). One hypothesis is that intensive/excessive exercise may result in an addicted state (i.e. tolerance and physical dependence) to the effects of endocannabinoids which may partially play a role in the preoccupation in excessive exercising in AN. However, these speculations have yet to be validated in the context of AN.

Alterations in neuropeptides such as corticotropin releasing hormone, melanin concentrating hormone, melanocortin 4 rceptor; $\alpha \mathrm{MSH}$ : Alfa melanosit "stimulating" hormon; NPY: Nöropeptid Y; POMC: Propiomelanokortin; TRH: Tirotropin "releasing" hormone, have been considered to be a consequence of serotonergic, dopaminergic and opioid alterations in eating disorders (Annagür and Bozkurt, 2012). Thus, the neuroendocrinal alterations both prior to and as a result of weight loss following AN have not been discussed in this review (for a review on eating disorders and endocrinological alterations see Zincir, 2014).

\section{Treatment Applications}

\section{Interventions with Neuromodulatory Techniques}

Neuromodulatory techniques such as TMS and DBS have been shown to have therapeutic potential as valuable option for weight restoration for patients with several treatment-refractory psychiatric disorders (Mayberg et al. 2005, Bewernick et al. 2010, McLaughlin et al. 2013).

DBS is a reversible neurosurgical procedure that drives continuous, high-frequency stimulation of the targeted brain areas that has gained attention as a treatment agent for AN patients (see for details Oudijn et al. 2013). In AN cortico-limbo-striatal circuits (Friederich et al. 2012) that have been suggested to underlie pathological behaviors in AN are commonly targeted for neuromodulation via DBS (Mayberg et al. 2005, Israel et al. 2010, Lipsman et al. 2013, Zhang et al. 2013). Specifically, weight recovery was reported in AN patients at the 12-month $(\mathrm{N}=2)$ (Wang et al. 2013) and 38-month follow-up ( $\mathrm{N}=4)$ (Wu et al. 2013) after DBS in NAc, a part of the ventral striatum. Another study using PET scan showed decreases in the hypermetabolism of the frontal lobe, hippocampus, and lentiform nucleus 6 months after the NAc-targeted DBS intervention (N=4) (Zhang et al. 2013). Significant activity reductions in the ACC and insula, as well as activity increases in the parietal lobe have been shown after 6 months 
following a DBS procedure $(\mathrm{N}=6)$ in subgenual cingulate cortex (SCC) (Lipsman et al. 2013). Israel et al. (2010) reported a lasting remission (several years) of AN following a SCC-targeted DBS treatment despite relapses in the depressive episodes in a case report of a patient with a long history of $\mathrm{AN}$ and depression. The technique is yet at the investigational stage, and the normalization of body weight after DBS does not necessarily translate into the normalization of other AN symptomatology (e.g. distorted body image etc). Moreover, the decision for such invasive techniques for psychiatric disorders requires specific criteria to define a treatment-refractoriness in AN (Couturier and Lock 2006, Hutton 2013). Thus, it may yet be premature to suggest DBS as a treatment for $\mathrm{AN}$ as there are several ethical issues raised regarding the side effects and the generalizability of the results (Nestler et al. 2013, de Zwaan and Schlaepfer 2013, Maslen et al. 2015). However, it undeniably provides fundamental insight for the underlying neural substrates of $\mathrm{AN}$, especially when there is a lack of bona fide animal models in AN research.

The use of repetitive TMS (rTMS) in eating disorders is a novel approach proposed as a therapeutic method for AN (Tsai 2005). One session of high frequency repetitive rTMS delivered to the left DLPFC has been shown to reduce subjective ratings related to the eating disorder (e.g. urge to restrict, feeling full etc.) during the exposure to visual and real food stimuli (van den Eynde et al. 2013). Similar findings have been reported for the improvement in eating disorder symptomatology and mood after 19-20 sessions of neuronavigated rTMS, and these changes persisted or continued to improve at follow-up (McClelland et al. 2013).

\section{Psychopharmacological Interventions}

The reports on the neurochemical substrates allowed researchers to develop pharmacological agents combating AN. Although lower serotonergic activity has been implicated in AN pathology, serotonin reuptake inhibitors (SSRI) have not been effective in treating AN and, in some cases, may contribute to further weight loss (Vaswani et al. 2003). Specifically, no significant differences in neural activity in response to food stimuli were found between those who were taking SSRIs and those who were not (Brooks et al. 2011). However, in some small sized clinical trials, olanzapine, atypical antipsychotics effective on both 5-HT and DA system among others, has been shown to results in improvements in body weight, eating behavior and some AN-related psychopathology (i.e. obsession with body image and fear of gaining weight, anxiety) (Brewerton 2012, Milano et al. 2013, Kesic and Lakic 2014). Similarly, a case study with 4 adolescents with AN using aripiprizole, a partial DA agonist that works as an antagonist on 5-HT, showed some benefits for the patients (Frank 2016). However, when the context of an intense therapeutic inpatient treatment environment is considered, it seems that the effect of these treatments to become insignificant to none. Similarly, a preliminary report including results from seven randomized control trials $(\mathrm{N}=201)$ investigating the effects of second generation antipsychotics (olanzapine, quetiapine, risperidone) in AN subjects showed that none of the antipsychotics was significantly superior to placebo/no treatment in achieving BMI gain and no significant between-group difference in mean BMI change when comparing the pooled group of drugs with the control pool (Dold et al. 2015). Thus, although it was reported that the medication was well tolerated by AN 
patients (Dold et al. 2015), more research is required to categorize which AN patients could potentially benefit from such interventions.

Endorphins have been implicated in the eating behavior pathology (Yim et al. 1984), and opioid antagonists such as Naltrexone (Marrazzi et al. 1997) and Tramadol (Mendelson 2001), a selective mu opiate agonist (with significant norepinephrine and serotonin agonistic effects), have been reported to be useful in the treatment of AN. DCycloserine is a glutamatergic (NMDA) receptor agonist was shown to help increase $\mathrm{BMI}$ in AN patients with a potential mechanism related to learning (Levinson et al. 2015) possibly based on the glutamate signaling (Hofmann et al. 2013, Siegmund et al. 2011). Increased plasma levels of anandamide, an andogenous ligand of the canabinoid receptors (CB1R), was found in women with $\mathrm{AN}$ and binge eating disorder, BED, (an eating disorder of uncontrollable bingeing behavior large amount of food) (Monteleone et al. 2005). Although it should be noted that the plasma levels may not necessarily reflect the central levels of anandamine, the findings from a PET imaging study also indicated a possible increase in central CB1R in cortical and subcortical brain areas in AN patients (vs. age-matched healthy controls) (Gérard et al. 2011). Regionally, an increase of CB1Rs in the insular cortex in both $\mathrm{AN}$ and $\mathrm{BN}$ patients, has been reported (Gérard et al. 2011). Adding to the hypothesis of altered endocannabinoid signaling, polymorphisms for gene encoding the CB1R (Monteleone et al. 2009) and elevated levels of CB1R mRNA in the blood (Frieling et al. 2009) were found in AN and bulimia nervosa (an eating disorder of uncontrollable food binging followed by purging) patients compared to healthy controls. Moreover, in both AN and BN, polymorphism has been reported in the gene encoding fatty acid amide hydrolase (FAAH) (Monteleone et al. 2009), and enzyme degrading anandamine and of which inhibitors leading to elevated anandamide levels with its potential therapeutic use (Gaetani et al. 2009, Hwang et al. 2010). These results, the very least, may hint on the rewarding aspects of the disordered patterns of eating behavior in AN along with BN and BED albeit for the latter two, of which eating behavior aberrations are at the opposite end of the spectrum than AN. Thus, therapeutic use of the endocannabinoid signaling may be of value in the treatment of eating disorders. Few clinical trials reported increased appetite and body weight in cachexic cancer and AIDS patients following the administration of cannabinoid agonists (Jatoi et al. 2002). From the same token, CB1 agonism has been suggested as a therapeutic orexigenic in $\mathrm{AN}$ and few studies used agents such as THC (psychotropic component of cannabis plant that binds to cannabinoid receptors) and dronabinol (a synthetic form of cannabionoid receptor agonist), and reported showed modest weight gain in AN (Nelson et al. 1994, Gross et al. 2013).

\section{Neuropsychological Interventions}

Cognitive-behavioral therapies (CBT) have been used in AN (Fairburn et al. 2009, Zipfel et al. 2014) and was reported to the superior to interpersonal psychotherapy (Fairburn et al. 2015). Results from studies using cognitive remediation therapy (CRT) as a supplement for inpatient $\mathrm{AN}$, a pre-treatment focusing on increasing awareness of cognitive style (Davies et al. 2005, Abbate-Daga et al. 2012, Lang et al. 2015) showed improvements in AN patients, with the most benefit for those who have difficulties with cognitive flexibility regardless of the CRT (Tchanturia et al. 2012). Neurocognitive feedback where direct neuropsychological task feedback is given with healthy and 
eating disorder forms is suggested as an outpatient supplementary strategy based on motivational enhancement therapy is also suggested (Lopez et al. 2008b). The effects of these techniques are potentially subserved by the neural pathways of which activity may aid to predict favorable outcome to cognitive treatments. Therefore, incorporating multiple modules considering the neurological substrates of AN (Hartman et al. 2015) into standard clinical treatment of eating disorders has potential to improve treatment outcome by targeting poor flexibility and reward re-evaluation as a cognitive maintaining factor.

\section{Limitations}

One of the limitations of the current literature regarding the research on structural and functional correlates of AN may be related to the methodological aspects. Regional VBM has been considered superior than the region of interest (ROI) analysis and was shown to give a more rapid and extensive survey of different gray and white matter alterations. VBM approach provides global and regional assessment of changes in volume and density of gray and white matter and, unlike ROI-based morphometric method, does not require a priori decision regarding which brain regions are more relevant to the target behavior/cognitive process. A further limitation is the lack of basic research with animal models. Most models involve forced calorie restriction of rodents and activity-based or stress-based anorexia all of which may have their advantages and disadvantages and limited face validity. Given the limitations of the study of this disorder in humans due to ethical issues and its intricacies, it is especially imperative to develop animal models that allow us to further characterize the neurobiological, physiological and behavioral aspects of this disorder. Possible peripheral nervous system alterations should also be investigated (Aras et al 2015)

\section{Conclusion}

Although there are data gaps and inconsistencies in the literature, there are common findings that are summarized in this review: Majority of the neuroimaging studies reported reductions in GMV in AN patients which may be ameliorated following weight recovery whereas reports on alterations in WMV and CSF have not been consistent. There seems to be a considerable amount of evidence supporting the view that neural correlates of abnormal cognitive processes (e.g. cognitive inflexibility, setshifting etc) can be identified in acute and recovered AN patients. This supports that the cognitive impairment may not be related solely on malnutrition and may possess causality and thus may be useful as a biomarker to predict treatment response. However, the multiple symptomatology in $\mathrm{AN}$ implies a potential dysregulation in several and interactive neural circuits with both afferent and efferent projections underlying multiple functions. Studies commonly implicated that the disruption of the reward network in patients with AN suggests lower efficiency of bottom-up signal filtering that may be overridden by the greater top-down signal, which might be involved in set-shifting (i.e. rigid response to criteria-change, elevated preservative responses, switching errors). Thus AN should be considered a multifactorial disorder with the possible alterations in several neurocircuits related to reward value and emotional processing, cognitive control as well as metabolic and hormonal processes related directly to food intake, 
which may be difficult to detangle. Therefore, it is difficult to ascribe a particular region as a substrate for a single symptom and thus a complex strategy for treatment and recovery may be required as both psychophamcological agents and also multimodal psychotherapies that are effective on more than one component.

To sum up, it seems that there is a need to conduct long-term studies with larger sample sizes to help elucidate, 1) the potential long-lasting deficits, 2) whether a volume loss applies to all or just selective patients with AN, 3) whether the psychopathology in $\mathrm{AN}$ is a cause or consequence of a starvation state, 4) the requirements for a complete recovery of the brain to prevent relapse. It is important to note that the learning abilities and cognitive flexibility necessary for a successful long-term psychological treatment may only be present after successful partial weight rehabilitation as weight catabolic state affects brain activity. Thus, interventions facilitating learning (i.e. cognitive remediation therapy) may also be beneficial as a support therapy leading healthy habit formation along with targeting associated clinical features such as ED rituals, social anxiety, self-harm, poor set-shifting and poor self-esteem alongside a module fostering increased flexibility. Extensive (re-) training of these cognitive functions might positively influence short- and long-term outcome of these patients. Future research aimed at identifying drugs that act on neurotransmitter systems (dopamine, serotonin, endocannabinoids, glutamate) begs for attention and will possibly lead to developments for novel pharmacotherapies for treating AN. Moreover, familial studies with twins and siblings at neurocognitive, neuroanatomical and genetic levels will help researchers detect preexisting changes in the brain predisposing individuals and thus will shed light on causality regarding whether it is best understood as a biomarker or heritable endophenotype.

\section{Acknowledgement}

The author wishes to thank Ali Pamir Kaplan, Elif Özgüder, Umut Pektürk for their editorial contributions to this review.

\section{References}

Abbate-Daga G, Buzzichelli S, Marzola E, Amianto F, Fassino S (2012) Effectiveness of cognitive remediation therapy (CRT) in anorexia nervosa: a case series. J Clin Exp Neuropsychol, 34:1009-1015.

APA (American Psychiatric Association) (2013) Diagnostic and Statistical Manual of Mental Disorders 5th edition (DSM-5). Washington DC, American Psychiatric Association.

Annagür BB, Bozkurt Zincir S (2012) Anoreksiya nervozada hormonal değişimler. Düşünen Adam Psikiyatri ve Nörolojik Bilimler Dergisi, 25:63-69.

Aras B, Kesikburun S, Güzelküçük Ü, Yaşar E, Tan AK (2016) Kontrolsüz kilo kaybı sonrası gelişen şiddetli polinöropati. Fiziksel Tıp ve Rehabilitasyon Bilimleri Dergisi, 19:31-34.

Ariyasu H, Takaya K, Tagami T, Ogawa Y, Hosoda K, Akamizu T et al. (2001) Stomach is a major source of circulating ghrelin, and feeding state determines plasma ghrelin-like immunoreactivity levels in humans. J Clin Endocrinol Metab, 86:4753-4758.

Artmann H, Grau H, Adelmann M, Schleiffer R (1985) Reversible and non-reversible enlargement of cerebrospinal fluid spaces in anorexia nervosa. Neuroradiology, 27:304-312.

Avena NM, Bocarsly ME (2012) Dysregulation of brain reward systems in eating disorders: neurochemical information from animal models of binge eating, bulimia nervosa, and anorexia nervosa. Neuropharmacology, 63:87-96.

Bailer UF, Frank GK, Henry SE, Price JC, Meltzer CC, Weissfeld L et al. (2005) Altered brain serotonin 5-HT1A receptor binding after recovery from anorexia nervosa measured by positron emission tomography and [carbonyl11C] WAY-100635. Arch Gen Psychiatry, 62:1032-1041.

Bailer UF, Frank GK, Henry SE, Price JC, Meltzer CC, Mathis CA et al. (2007) Exaggerated 5-HT1A but normal 5-HT2A receptor 
activity in individuals ill with anorexia nervosa. Biol Psychiatry, 61:1090-1099.

Bailer UF, Frank GK, Henry SE, Price JC, Meltzer CC, Becker C et al. (2007b) Serotonin transporter binding after recovery from eating disorders. Psychopharmacology (Berl), 195:315-324.

Bailer UF, Frank GK, Price JC, Meltzer CC, Becker C, Mathis CA et al. (2013) Interaction between serotonin transporter and dopamine D2/D3 receptor radioligand measures is associated with harm avoidant symptoms in anorexia and bulimia nervosa. Psychiatry Res, 211:160-168.

Baldo B, Kelley A (2007) Discrete neurochemical coding of distinguishable motivational processes: insights from nucleus accumbens control of feeding. Psychopharmacology (Berl), 191:439-459.

Bardone-Cone AM, Wonderlich SA, Frost RO, Bulik CM, Mitchell JE, Uppala S et al. (2007) Perfectionism and eating disorders: Current status and future directions. Clin Psychol Rev, 27:384-405.

Bär KJ, de la Cruz F, Berger S, Schultz CC,Wagner G (2015) Structural and functional differences in the cingulate cortex relate to disease severity in anorexia nervosa. J Psychiatry Neurosci, 40:269-279

Bergen AW, Yeager M, Welch RA, Haque K, Ganjei JK, van den Bree MB et al. (2005) Association of multiple DRD2 polymorphisms with anorexia nervosa. Neuropsychopharmacology, 30:1703-1710.

Berridge KC (1996) Food reward: brain substrates of wanting and liking. Neurosci Biobehav Rev, 20:1-25.

Berthoud HR (2002) Multiple neural systems controlling food intake and body weight. Neurosci Biobehav Rev, 26:393-428.

Bewernick BH, Hurlemann R, Matusch A, Kayser S, Grubert C, Hadrysiewicz B et al. (2010) Nucleus accumbens deep brain stimulation decreases ratings of depression and anxiety in treatment-resistant depression. Biol Psychiatry, 67:110-116.

Biezonski D, Cha J, Steinglass J, Posner J, (2016). Evidence for thalamocortical circuit abnormalities and associated cognitive dysfunctions in underweight individuals with anorexia nervosa. Neuropsychopharmacology, 41:1560-1568.

Blundell JE, Goodson S, Halford JC (2001) Regulation of appetite: role of leptin in signalling systems for drive and satiety. Int J Obes Relat Metab Disord, 25:29-34.

Bomba M, Riva A, Veggo F, Grimaldi M, Morzenti S, Neri et al. (2013) Impact of speed and magnitude of weight loss on the development of brain trophic changes in adolescents with anorexia nervosa: a case control study. Ital J Pediatr, 39:14.

Bomba M, Riva A, Morzenti S, Grimaldi M, Neri F, Nacinovich R (2015) Global and regional brain volumes normalization in weightrecovered adolescents with anorexia nervosa: preliminary findings of a longitudinal voxel-based morphometry study. Neuropsychiatr Dis Treat, 11:637-645.

Boone L, Claes L, Luyten P (2014) Too strict or too loose? perfectionism and impulsivity: The relation with eating disorder symptoms using a person-centered approach. Eat Behav, 15:17-23.

Bowden PK, Touyz SW, Rodriguez PJ, Hensley R, Beumont PJ (1989) Distorting patient or distorting instrument? Body shape disturbance in patients with anorexia nervosa and bulimia. Br J Psychiatry, 155:196-201.

Bremner JD, Licinio J, Darnell A, Krystal JH, Owens MJ, Southwick SM et al. (1997) Elevated CSF corticotropin-releasing factor concentrations in posttraumatic stress disorder. Am J Psychiatry, 154:624-629.

Bressler SL, Menon V (2010) Large-scale brain networks in cognition: emerging methods and principles. Trends Cogn Sci, 14:277290.

Brewerton TD (2012) Antipsychotic agents in the treatment of anorexia nervosa: neuropsychopharmacologic rationale and evidence from controlled trials. Curr Psychiatry Rep, 14:398-405.

Broft A, Slifstein M, Osborne J, Kothari P, Morim S, Shingleton R et al. (2015) Striatal dopamine type 2 receptor availability in anorexia nervosa. Psychiatry Res, 233:380-387.

Brooks SJ, Barker GJ, O'Daly OG, Brammer M, Williams SC, Benedict C et al. (2011) Restraint.of appetite and reduced regional brain volumes in anorexia nervosa: A voxel-based morphometric study. BMC Psychiatry, 11:179.

Brown KM, Bujac SR, Mann ET, Campbell DA, Stubbins MJ, Blundell JE (2007) Further evidence of association of OPRD1 \& HTR1D Polymorphisms with susceptibility to anorexia nervosa. Biol Psychiatry, 61:367-373.

Bush G, Luu P, Posner MI (2000) Cognitive and emotional influences in anterior cingulate cortex. Trends Cogn Sci, 4:215-222.

Bush G, Vogt BA, Holmes J, Dale AM, Greve D, Jenike MA et al. (2002) Dorsal anterior cingulate cortex: a role in reward-based decision making. Proc Natl Acad Sci U S A, 99:523-528.

Calati R, De Ronchi D, Bellini M, Serretti A (2011) The 5-HTTLPR polymorphism and eating disorders: a meta-analysis. Int J Eat Disord, 44:191-199.

Casiero D, Frishman WH (2016) Cardiovascular complications of eating disorders. Cardiol Rev, 14:227-231.

Carter CS, Braver TS, Barch DM, Botvinick MM, Noll D, Cohen JD (1998) Anterior cingulate cortex, error detection, and the online monitoring of performance. Science, 280(5364):747-749.

Casiero D, Frishman WH (2006) Cardiovascular complications of eating disorders. Cardiol Rev, 14:227-231.

Cassin SE, von Ranson KM (2005) Personality and eating disorders: a decade in review. Clin Psychol Rev, 25:895-916. 
Castellini G, Polito C, Bolognesi E, D'Argenio A, Ginestroni A, Mascalchi M et al. (2013) Looking at my body. Similarities and differences between anorexia nervosa patients and controls in body image visual processing. Eur Psychiatry, 28:427-435.

Castro-Fornieles J, Bargalló N, Lázaro L, Andrés S, Falcon C, Plana MT et al. (2009) A cross-sectional and follow-up voxel-based morphometric MRI study in adolescent anorexia nervosa. J Psychiatr Res, 43:331-340.

Cavanna AE (2006) The precuneus: A review of its functional anatomy and behavioural correlates. Brain, 129:564-583.

Chikama M, McFarland NR, Amaral DG, Haber SN (1997) Insular cortical projections to functional regions of the striatum correlate with cortical cytoarchitectonic organization in the primate. J Neurosci, 17:9686-9705.

Chui HT, Christensen BK, Zipursky RB, Richards BA, Hanratty MK, Kabani NJ et al. (2008). Cognitive function and brain structure in females with a history of adolescent-onset anorexia nervosa. Pediatrics, 122:426-437.

Cloninger CR, Bayon C, Svrakic DM (1998) Measurement of temperament and character in mood disorders: a model of fundamental states as personality types. J Affect Disord, 51:21-32.

Collantoni E, Michelon S, Tenconi E, Degortes D, Titton F, Manara R et al. (2016) Functional connectivity correlates of response inhibition impairment in anorexia nervosa. Psychiatry Res, 247:9-16.

Connan F, Campbell IC, Katzman M, Lightman SL, Treasure J (2003) A neurodevelopmental model for anorexia nervosa. Physiol Behav, 79:13-24.

Connan F, Murphy F, Connor SE, Rich P, Murphy T, Bara-Carill N et al. (2006) Hippocampal volume and cognitive function in anorexia nervosa. Psychiatry Res, 146:117-125.

Couturier J, Lock J (2006) What is recovery in adolescent anorexia nervosa? Int J Eat Disord, 39:550-555.

Cowdrey FA, Harmer CJ, Park RJ, McCabe C (2012) Neural responses to emotional faces in women recovered from anorexia nervosa. Psychiatry Res, 201:190-195.

Craig AD (2010) The sentient self. Brain Struct Funct, 214:563-577.

Cserjési R, Vermeulen N, Lénárd L, Luminet 0 (2011) Reduced capacity in automatic processing of facial expression in restrictive anorexia nervosa and obesity. Psychiatry Res, 188:253-257.

Daw ND, Kakade S, Dayan P (2002) Opponent interactions between serotonin and dopamine. Neural Netw, 15:603-616.

Dawe S, Loxton NJ (2004) The role of impulsivity in the development of substance use and eating disorders. Neurosci Biobehav Rev, 28:343-51.

Davies H, Tchanturia K (2005) Cognitive remediation therapy as an intervention for acute anorexia nervosa: a case report. Eur Eat Disord Rev, 13:311-316.

de Araujo IE (2004) Representation in the human brain of food texture and oral fat. J Neurosci, 24:3086-3093.

Delgado MR, Nystrom LE, Fissell C, Noll DC, Fiez JA (2000) Tracking the hemodynamic responses to reward and punishment in the striatum. J Neurophysiol, 84:3072-3077.

De Zwaan M, Schlaepfer TE (2013) Not too much reason for excitement: deep brain stimulation for anorexia nervosa. Eur Eat Disord Rev, 21:509-511.

Diamond A (1990) Developmental time course in human infants and infant monkeys, and the neural bases of, inhibitory control in reaching. Ann N Y Acad Sci, 608: 637-669.

Dietrich A, McDaniel WF (2004) Endocannabinoids and exercise. Br J Sports Med, 38:536-541.

Dold M, Aigner M, Treasure J, Kasper S (2015) Are second-generation antipsychotic drugs effective in treating anorexia nervosa? Eur Psychiatry, 30:1339.

Dostálová I, Kopský V, Dušková J, Papežová H, Pacák K, Nedvídková J (2005) Leptin concentrations in the abdominal subcutaneous adipose tissue of patients with anorexia nervosa assessed by in vivo microdialysis. Regul Pept, 128:63-68.

Downing PE (2001) A cortical area selective for visual processing of the human body. Science, 293:2470-2473.

Fairburn CG, Cooper Z, Doll HA, O'Connor ME, Bohn K, Hawker DM et al. (2009) Transdiagnostic cognitive-behavioral therapy for patients with eating disorders: a two-site trial with 60-week follow-up. Am J Psychiatry, 166:311-319.

Fairburn CG, Bailey-Straebler S, Basden S, Doll HA, Jones R, Murphy R et al. (2015) A transdiagnostic comparison of enhanced cognitive behaviour therapy (CBT-E) and interpersonal psychotherapy in the treatment of eating disorders. Behav Res Ther, 70:64-71.

Favaro A, Santonastaso P, Manara R, Bosello R, Bommarito G, Tenconi E et al. (2012) Disruption of visuospatial and somatosensory functional connectivity in anorexia nervosa. Biol Psychiatry, 72:864-870.

Fellows LK (2007) The role of orbitofrontal cortex in decision making. Ann N Y Acad Sci, 1121:421-430.

Ferro AM, Brugnolo A, De Leo C, Dessi B, Girtler N, Morbelli S et al. (2005) Stroop interference task and single-photon emission tomography in anorexia: a preliminary report. Int J Eat Disord, 38:323-329.

Fladung AK, Grön G, Grammer K, Herrnberger B, Schilly E, Grasteit S et al. 2010. A neural signature of anorexia nervosa in the ventral striatal reward system. Am J Psychiatry, 167:206-212. 
Foerde K, Steinglass JE, Shohamy, Walsh BT (2015) Neural mechanisms supporting maladaptive food choices in anorexia nervosa. Nat Neurosci, 18:1571-1573.

Fonville L, Giampietro V, Williams SCR, Simmons A, Tchanturia K (2014) Alterations in brain structure in adults with anorexia nervosa and the impact of illness duration. Psychol Med, 44:1965-1975.

Frank GK, Kaye WH, Meltzer CC, Price JC, Greer P, McConaha C et al. (2002) Reduced 5-HT2A receptor binding after recovery from anorexia nervosa. Biol Psychiatry, 52:896-906.

Frank GK, Bailer UF, Henry SE, Drevets W, Meltzer CC, Price JC et al. (2005) Increased Dopamine D2/D3 receptor binding after recovery from anorexia nervosa measured by positron emission tomography and [11C]Raclopride. Biol Psychiatry, 58:908-912.

Frank GK, Reynolds JR, Shott ME, Jappe L, Yang TT, Tregellas JR et al. (2012) Anorexia nervosa and obesity are associated with opposite brain reward response. Neuropsychopharmacology, 37:2031-2046.

Frank GK, Shott ME, Hagman J0, Yang TT (2013) Localized brain volume and white matter integrity alterations in adolescent anorexia nervosa. J Am Acad Child Adolesc Psychiatry, 52:1066-1075.

Frank GWK (2016) Aripiprazole, a partial dopamine agonist to improve adolescent anorexia nervosa-a case series. Int J Eat Disord 49:529-533.

Friederich HC, Kumari V, Uher R, Riga M, Schmidt U, Campbell IC et al. (2006) Differential motivational responses to food and pleasurable cues in anorexia and bulimia nervosa: a startle reflex paradigm. Psychol Med, 36:1327-1335.

Friederich HC, Brooks S, Uher R, Campbell IC, Giampietro V, Brammer M et al. (2010) Neural correlates of body dissatisfaction in anorexia nervosa. Neuropsychologia, 48:2878-2885.

Friederich HC, Walther S, Bendszus M, Biller A, Thomann P, Zeigermann S et al. (2012) Grey matter abnormalities within corticolimbic-striatal circuits in acute and weight-restored anorexia nervosa patients. Neuroimage, 59:1106-1113.

Frieling $H$, Albrecht $H$, Jedtberg S, Gozner A, Lenz B, Wilhelm J et al. (2009) Elevated cannabinoid 1 receptor mRNA is linked to eating disorder related behavior and attitudes in females with eating disorders. Psychoneuroendocrinology, 34:620-624.

Friston KJ, Buechel C, Fink GR, Morris J, Rolls E, Dolan RJ (1997) Psychophysiological and modulatory interactions in neuroimaging. Neuroimage, 6:218-229.

Gaetani S, Dipasquale P, Romano A, Righetti L, Cassano T, Piomelli D et al. (2009) The endocannabinoid system as a target for novel anxiolytic and antidepressant drugs. Int Rev Neurobiol, 85:57-72.

Garrett AS, Lock J, Datta N, Beenhaker J, Kesler SR, Reiss AL (2014) Predicting clinical outcome using brain activation associated with set-shifting and central coherence skills in anorexia nervosa. J Psychiatric Res, 57:26-33.

Gaudio S, Nocchi F, Franchin T, Genovese E, Cannatà V, Longo D et al. (2011) Gray matter decrease distribution in the early stages of anorexia Nervosa restrictive type in adolescents. Psychiatry Res, 191:24-30.

Geisler D, Borchardt V, Lord AR, Boehm I, Ritschel F, Zwipp J et al. (2016) Abnormal functional global and local brain connectivity in female patients with anorexia nervosa. J Psychiatry Neurosci, 41:6-15.

Gérard N, Pieters G, Goffin K, Bormans G, Van Laere K (2011) Brain type 1 cannabinoid receptor availability in patients with anorexia and bulimia nervosa. Biol Psychiatry, 70:777-784.

Ghahremani DG, Lee B, Robertson CL, Tabibnia G, Morgan AT, De Shetler, N et al. (2012) Striatal dopamine D2/D3 receptors mediate response inhibition and related activity in frontostriatal neural circuitry in humans. J Neurosci, 32:7316-7324.

Giordano GD, Renzetti P, Parodi RC, Foppiani L, Zandrino F, Giordano, G et al. (2001) Volume measurement with magnetic resonance imaging of hippocampus-amygdala formation in patients with anorexia nervosa. J Endocrinol Invest, 24:510-514.

Goethals I, Vervaet M, Audenaert K, Jacobs F, Ham H, Van de Wiele C et al. (2007) Differences of cortical 5-HT 2A receptor binding index with SPECT in subtypes of anorexia nervosa: relationship with personality traits? J Psychiatric Res, 41:455-458.

Gold PW, Gwirtsman H, Avgerinos PC, Nieman LK, Gallucci WT, Kaye W et al. (1986) Abnormal hypothalamic-pituitary-adrenal function in anorexia nervosa. N Engl J Med, 314:1335-1342.

Golden NH, Ashtari M, Kohn MR, Patel M, Jacobson MS, Fletcher A et al. (1996) Reversibility of cerebral ventricular enlargement in anorexia nervosa, demonstrated by quantitative magnetic resonance imaging. J Pediatr, 128:296-301.

Goldzak-Kunik G, Friedman R, Spitz M, Sandler L, Leshem M (2012) Intact sensory function in anorexia nervosa. Am J Clin Nutr, 95:272-282.

Gorwood P, Kipman A, Foulon C (2003) The human genetics of anorexia nervosa. Eur J Pharmacol, 480:163-170.

Green MW, Elliman NA, Wakeling A, Rogers PJ (1996) Cognitive functioning, weight change and therapy in anorexia nervosa. J Psychiatr Res, 30:401-410.

Gross H, Ebert MH, Faden VB, Goldberg SC, Kaye WH, Caine ED et al. (1983) A double-blind trial of [DELTA] 9tetrahydrocannabinol in primary anorexia nervosa. J Clin Psychopharmacol, 3:165-171.

Guillaume S, Gorwood P, Jollant F, Van den Eynde F, Courtet P, Richard-Devantoy S (2015) Impaired decision-making in symptomatic anorexia and bulimia nervosa patients: a meta-analysis. Psychol Med, 45:3377-3391. 
Güney E, Kuruoğlu AÇ (2007) Yeme bozukluklarinda beyin görüntüleme yöntemleri. Klinik Psikiyatri Dergisi, 10:93-101.

Haase L, Cerf-Ducastel B, Murphy C (2009) Cortical activation in response to pure taste stimuli during the physiological states of hunger and satiety. Neuroimage, 44:1008-1021.

Haleem DJ, Haider S (1996) Food restriction decreases serotonin and its synthesis rate in the hypothalamus. Neuroreport, 7:11531156.

Hartmann AS, Thomas JJ, Greenberg JL, Rosenfield EH, Wilhelm S (2015) Accept, distract, or reframe? an exploratory experimental comparison of strategies for coping with intrusive body image thoughts in anorexia nervosa and body dysmorphic disorder. Psychiatry Res, 225:643-650.

Harvey T, Troop NA, Treasure JL, Murphy T (2002) Fear, disgust, and abnormal eating attitudes: a preliminary study. Int J Eat Disord, 32:213-218.

Hay P (2013) A systematic review of evidence for psychological treatments in eating disorders: 2005-2012. Int J Eat Disord, 46:462-469.

Hayes DJ, Lipsman N, Chen DQ, Woodside DB, Davis KD, Lozano AM et al. (2015) Subcallosal cingulate connectivity in anorexia nervosa patients differs from healthy controls: a multi-tensor tractography study. Brain Stimul, 8:758-768.

Hikosaka 0, Isoda M (2010) Switching from automatic to controlled behavior: cortico-basal ganglia mechanisms. Trends Cogn Sci, 14:154-161.

Hinton EC, Parkinson JA, Holland AJ, Arana FS, C Roberts A, Owen AM (2004) Neural contributions to the motivational control of appetite in humans. Eur $J$ Neurosci, 20:1411-1418.

Hofmann, SG, Smits JA, Rosenfield D, Simon N, Otto MW, Meuret AE et al. (2013) D-Cycloserine as an augmentation strategy with cognitive-behavioral therapy for social anxiety disorder. Am J Psychiatry, 170:751-758.

Holliday J, Tchanturia K, Landau S, Collier D, Treasure J (2005) Is impaired set-shifting an endophenotype of anorexia nervosa? Am J Psychiatry, 162:2269-2275.

Hudson J, Hiripi E, Pope HG, Kessler RC (2007) The prevalence and Correlates of eating disorders in the national Comorbidity survey replication. Biol Psychiatry, 61:348-358.

Husain MM, Black KJ, Doraiswamy PM, Shah SA, Rockwell WK, Ellinwood EH et al. 1992. Subcortical brain anatomy in anorexia and bulimia. Biol Psychiatry, 31:735-738.

Hutton P (2013) Deep brain stimulation for anorexia nervosa. Lancet, 382:305-306.

Ishibashi R, Ralph MAL, Saito S, Pobric G (2011) Different roles of lateral anterior temporal lobe and inferior parietal lobule in coding function and manipulation tool knowledge: evidence from an rTMS study. Neuropsychologia, 49:1128-1135.

Hwang J, Adamson C, Butler D, Janero DR, Makriyannis A, Bahr BA (2010) Enhancement of endocannabinoid signaling by fatty acid amide hydrolase inhibition: a neuroprotective therapeutic modality. Life Sci, 86:615-623.

Israël M, Steiger H, Kolivakis T, McGregor L and Sadikot AF (2010) Deep brain stimulation in the Subgenual Cingulate cortex for an intractable eating disorder. Biol Psychiatry, 67:53-54.

Jänsch C, Harmer C, Cooper MJ (2009) Emotional processing in women with anorexia nervosa and in healthy volunteers. Eat Behav, 10:184-191.

Jatoi A, Windschitl HE, Loprinzi CL, Sloan JA, Dakhil SR, Mailliard J.A et al. (2002) Dronabinol versus megestrol acetate versus combination therapy for cancer-associated anorexia: a North Central Cancer Treatment Group study. J Clin Oncol, 20:567-573.

Jean A, Laurent L, Bockaert J, Charnay Y, Dusticier N, Nieoullon A et al. (2012) The nucleus accumbens 5-HTR4-CART pathway ties anorexia to hyperactivity. Transl Psychiatry, 2:e203.

Jimura K, Chushak MS, Braver TS (2013) Impulsivity and self-control during Intertemporal decision making linked to the neural dynamics of reward value representation. J Neurosci, 33:344-357.

Jones BP, Duncan CC, Brouwers P, Mirsky AF (1991) Cognition in eating disorders. J Clin Exp Neuropsychol, 13:711-728.

Joos AA, Cabrillac E, Hartmann A, Wirsching M, Zeeck A (2009) Emotional perception in eating disorders. Int J Eat Disord, 42:318325.

Joos A, Klöppel S, Hartmann A, Glauche V, Tüscher 0, Perlov E et al. (2010) Voxel-based morphometry in eating disorders: Correlation of psychopathology with grey matter volume. Psychiatry Res, 182:146-151.

Joos A, Hartmann A, Glauche V, Perlov E, Unterbrink T, Saum B et al. (2011) Grey matter deficit in long-term recovered anorexia nervosa patients. Eur Eat Disord Rev, 19:59-63.

Kanakam N, Treasure J (2013) A review of cognitive neuropsychiatry in the taxonomy of eating disorders: state, trait, or genetic? Cogn Neuropsychiatry, 18:83-114.

Katzman DK (1997) A longitudinal magnetic resonance imaging study of brain changes in adolescents with anorexia nervosa. Arch Pediatr Adolesc Med, 151:793-797. 
Kaye WH, Gwirtsman HE, George DT, Ebert MH, Jimerson DC, Tomai TP et al. (1987) Elevated cerebrospinal fluid levels of immunoreactive corticotropin-releasing hormone in anorexia nervosa: relation to state of nutrition, adrenal function, and intensity of depression. J Clin Endocrinol Metab, 64:203-208.

Kaye WH, Frank GK, McConaha C (1999) Altered dopamine activity after recovery from restricting-type anorexia nervosa. Neuropsychopharmacology, 21:503-506.

Kaye WH, Frank GK, Bailer UF, Henry SE (2005) Neurobiology of anorexia nervosa: clinical implications of alterations of the function of serotonin and other neuronal systems. Int J Eat Disord, 37(S10):15-19.

Kaye W (2008) Neurobiology of anorexia and bulimia nervosa. Physiol Behav, 94:121-135.

Kaye WH, Fudge JL, Paulus M (2009) New insights into symptoms and neurocircuit function of anorexia nervosa. Nat Rev Neurosci, 10:573-584.

Kaye WH., Wierenga CE, Bailer UF, Simmons AN, Bischoff-Grethe A (2013) Nothing tastes as good as skinny feels: The neurobiology of anorexia nervosa. Trends Neurosci, 36:110-120.

Kazlouski D, Rollin MD, Tregellas J, Shott ME, Jappe LM, Hagman J0 et al. (2011) Altered fimbria-fornix white matter integrity in anorexia nervosa predicts harm avoidance. Psychiatry Res, 192:109-116.

Keating C, Tilbrook AJ, Rossell SL, Enticott PG, Fitzgerald PB (2012) Reward processing in anorexia nervosa. Neuropsychologia, 50:567-575.

Kerns JG (2004) Anterior cingulate conflict monitoring and adjustments in control. Science, 303:1023-1026.

Kesic A, Lakic A (2014) P.7.d.003 Olanzapine in treatment of adolescents with anorexia nervosa. Eur Neuropsychopharmacol, 24:721.

Kjaer TW, Nowak M, Lou HC (2002) Reflective self-awareness and conscious states: PET evidence for a common midline parietofrontal core. Neuroimage, 17:1080-1086.

Kim JH, Son YD, Kim HK, Lee SY, Cho SE, Kim YB (2011) Association of harm avoidance with dopamine D2/3 receptor availability in striatal subdivisions: a high resolution PET study. Biol Psychol, 87:164-167.

Kim KR, Ku J, Lee JH, Lee H, Jung YC (2012) Functional and effective connectivity of anterior insula in anorexia nervosa and bulimia nervosa. Neurosci Lett, 521:152-157.

King JA, Geisler D, Ritschel F, Boehm I, Seidel M, Roschinski B et al. (2015) Global cortical thinning in acute anorexia nervosa Normalizes following long-term weight restoration. Biol Psychiatry, 77:624-632.

Kingston K, Szmukler G, Andrewes D, Tress B, Desmond P (1996) Neuropsychological and structural brain changes in anorexia nervosa before and after refeeding. Psychol Med, 26:15-28.

Klump KL, Strober M, Bulik CM, Thornton L, Johnson C, Devlin B et al. (2004) Personality characteristics of women before and after recovery from an eating disorder. Psychol Med, 34:1407-1418.

Kojima S, Nagai N, Nakabeppu Y, Muranaga T, Deguchi D, Nakajo M et al. (2005) Comparison of regional cerebral blood flow in patients with anorexia nervosa before and after weight gain. Psychiatry Res, 140:251-258.

Kringelbach ML (2004) Food for thought: hedonic experience beyond homeostasis in the human brain. Neuroscience, 126:807819.

Kullmann S, Giel KE, Teufel M, Thiel A, Zipfel S, Preissl H (2014) Aberrant network integrity of the inferior frontal cortex in women with anorexia nervosa. Neurolmage Clin, 4:615-622.

Lambe EK (1997) Cerebral gray matter volume deficits after weight recovery from anorexia nervosa. Arch Gen Psychiatry, 54:537542.

Lang K, Treasure J, Tchanturia K (2015) Acceptability and feasibility of self-help cognitive remediation therapy for anorexia nervosa delivered in collaboration with carers: a qualitative preliminary evaluation study. Psychiatry Res, 225:387-394.

Lavagnino L, Amianto F, Mwangi B, D'Agata F, Spalatro A, Soares GBZ et al. (2016) The relationship between cortical thickness and body mass index differs between women with anorexia nervosa and healthy controls. Psychiatry Res, 248:105-109.

Lawrence AD, Dowson J, Foxall GL, Summerfield R, Robbins TW, Sahakian BJ (2003) Impaired visual discrimination learning in anorexia nervosa. Appetite, 40:85-89.

Lawson EA, Holsen LM, DeSanti R, Santin M, Meenaghan E, Herzog DB et al. (2013) Increased hypothalamic-pituitary-adrenal drive is associated with decreased appetite and hypoactivation of food-motivation neurocircuitry in anorexia nervosa. Eur J Endocrinol, 169:639-647.

Le Bihan D, Mangin JF, Poupon C, Clark CA, Pappata S, Molko N et al. (2001) Diffusion tensor imaging: concepts and applications. J Magn Reson Imaging, 13:534-546.

Lee Y, Lin PY (2010) Association between serotonin transporter gene polymorphism and eating disorders: a meta-analytic study. Int J Eat Disord, 43: 498-504.

Levinson CA, Rodebaugh TL, Fewell L, Kass AE, Riley EN, Stark L et al. (2015) D-Cycloserine facilitation of exposure therapy 
improves weight regain in patients with anorexia nervosa: a pilot randomized controlled trial. J Clin Psychiatry, 76:e787-e793.

Li W, Lai TM, Bohon C, Loo SK, McCurdy D, Strober M et al. (2015) Anorexia nervosa and body dysmorphic disorder are associated with abnormalities in processing visual information. Psychol Med, 45:2111-2122.

Lichtman JW, Sanes JR (2008) Ome sweet ome: what can the genome tell us about the connectome? Curr Opin Neurobiol, 18:346-353.

Lipsman N, Woodside DB, Giacobbe P, Hamani C, Carter JC, Norwood SJ et al. (2013) Subcallosal cingulate deep brain stimulation for treatment-refractory anorexia nervosa: a phase 1 pilot trial. Lancet, 381:1361-1370.

Lipsman N, Woodside DB, Lozano AM (2015) Neurocircuitry of limbic dysfunction in anorexia nervosa. Cortex, 62:109-118.

Lopez C, Roberts ME, Sepulveda AR, Treasure J (2008) Using an evidence-based approach to develop new tailored treatment for anorexia nervosa. In Psychological Responses to Eating Disorders and Obesity: Recent and Innovative Work Part II (Eds J Buckroyd, S Rother):39-54. Chichester, Wiley.

Lopez C, Tchanturia K, Stahl D, Booth R, Holliday J, Treasure J (2008) An examination of the concept of central coherence in women with anorexia nervosa. Int J Eat Disord, 41:143-152.

Lo Sauro C, Ravaldi C, Cabras PL, Faravelli C, Ricca V (2008) Stress, hypothalamic-pituitary-adrenal axis and eating disorders. Neuropsychobiology, 57:95-115.

Mainz V, Schulte-Rüther M, Fink GR, Herpertz-Dahlmann B, Konrad K (2012) Structural brain abnormalities in adolescent anorexia nervosa before and after weight recovery and associated hormonal changes. Psychosom Med, 74:574-582.

Margulies DS, Kelly AC, Uddin LQ, Biswal BB, Castellanos FX, Milham MP (2007) Mapping the functional connectivity of anterior cingulate cortex. Neuroimage, 37:579-588.

Marrazzi MA, Luby ED, Kinzie J, Munjal ID, Spector S (1997) Endogenous codeine and morphine in anorexia and bulimia nervosa. Life Sci, 60:1741-1747.

Martásková D, Slachtova L, Kemlink D, Záhoráková D, Papezova H (2009) Polymorphisms in serotonin-related genes in anorexia nervosa. the first study in czech population and meta-analyses with previously performed studies. Folia Biol (Praha), 55:192197.

Maslen H, Pugh J, Savulescu J (2015) The ethics of deep brain stimulation for the treatment of anorexia nervosa. Neuroethics, 8:215-230.

Matsumoto R, Kitabayashi Y, Narumoto J, Wada Y, Okamoto A, Ushijima Y et al. (2006) Regional cerebral blood flow changes associated with interoceptive awareness in the recovery process of anorexia nervosa. Prog Neuropsychopharmacol Biol Psychiatry, 30:1265-1270.

Mayberg HS, Lozano AM, Voon V, McNeely HE, Seminowizz D, Hamani C et al. (2005) Deep brain stimulation for treatmentresistant depression. Neuron, 45:651-660.

McAdams CJ, Krawczyk DC (2011) Impaired neural processing of social attribution in anorexia nervosa. Psychiatry Res, 194:54-63.

McClelland J, Bozhilova N, Nestler S, Campbell IC, Jacob S, Johnson-Sabine E et al. (2013) Improvements in symptoms following neuronavigated repetitive transcranial magnetic stimulation (rTMS) in severe and enduring anorexia nervosa: findings from two case studies. Eur Eat Disord Rev, 21:500-506.

McLaughlin NC, Didie ER, Machado AG, Haber SN, Eskandar EN et al. (2013) Improvements in anorexia symptoms after deep brain stimulation for intractable obsessive-compulsive disorder. Biol Psychiatry, 73:29-31.

Mendelson SD (2001) Treatment of anorexia nervosa with tramadol. Am J Psychiatry, 158:963-964.

Milano W, De Rosa M, Milano L, Riccio A, Sanseverino B, Capasso A (2013) The pharmacological options in the treatment of eating disorders. ISRN Pharmacol, 2013:352865.

Monteleone P, Di Lieto A, Tortorella A, Longobardi N, Maj M (2000) Circulating leptin in patients with anorexia nervosa, bulimia nervosa or binge-eating disorder: relationship to body weight, eating patterns, psychopathology and endocrine changes. Psychiatry Res, 94:121-129.

Monteleone P, Matias I, Martiadis V, De Petrocellis L, Maj M, Di Marzo V (2005) Blood levels of the endocannabinoid anandamide are increased in anorexia nervosa and in binge-eating disorder, but not in bulimia nervosa. Neuropsychopharmacology, 30:1216-1221.

Monteleone P, Bifulco M, Di Filippo C, Gazzerro P, Canestrelli B, Monteleone F et al. (2009) Association of CNR1 and FAAH endocannabinoid gene polymorphisms with anorexia nervosa and bulimia nervosa: evidence for synergistic effects. Genes Brain Behav, 8:728-732.

Monteleone P, Maj M (2013) Dysfunctions of leptin, ghrelin, BDNF and endocannabinoids in eating disorders: beyond the homeostatic control of food intake. Psychoneuroendocrinology, 38:312-330.

Mohr HM, Zimmermann J, Röder C, Lenz C, Overbeck G, Grabhorn R (2010) Separating two components of body image in anorexia nervosa using fMRI. Psychol Med, 40:1519-1529. 
Mühlau M, Gaser C, Ilg R, Conrad B, Leibl C, Cebulla MH et al. (2007) Gray matter decrease of the anterior cingulate cortex in anorexia nervosa. Am J Psychiatry, 164:1850-1857.

Nagahara Y, Nakamae T, Nishizawa S, Mizuhara Y, Moritoki Y, Wada Y et al. (2014) A tract-based spatial statistics study in anorexia nervosa: abnormality in the fornix and the cerebellum. Prog Neuropsychopharmacol Biol Psychiatry, 51:72-77.

Naruo, T, Nakabeppu Y, Deguchi D, Nagai N, Tsutsui, J, Nakajo M et al. (2001) Decreases in blood perfusion of the anterior cingulate gyri in anorexia nervosa restricters assessed by SPECT image analysis. BMC Psychiatry, 1:2.

Nelson K, Walsh D, Deeter P, Sheehan F (1994) A phase II study of delta-9-tetrahydrocannabinol for appetite stimulation in cancer-associated anorexia. J Palliat Care, 10:14-18.

Nestler EJ (2013) Treating the brain deep down: brain surgery for anorexia nervosa? Nat Med, 19:678-679.

Neumärker KJ, Bzufka WM, Dudeck U, Hein J, Neumärker U (2000) Are there specific disabilities of number processing in adolescent patients with anorexia nervosa? evidence from clinical and neuropsychological data when compared to morphometric measures from magnetic resonance imaging. Eur Child Adolesc Psychiatry, 9(Suppl2):Il111-121.

Nikendei C, Funiok C, Pfüller U, Zastrow A, Aschenbrenner S, Weisbrod M (2011) Memory performance in acute and weightrestored anorexia nervosa patients. Psychol Med, 41:829-838.

Nunn K, Frampton I, Gordon I, Lask B (2008) The fault is not in her parents but in her insula: a neurobiological hypothesis of anorexia nervosa. Eur Eat Disord Rev, 16:355-360.

Oberndorfer T, Simmons A, McCurdy D, Strigo I, Matthews S, Yang T et al. (2013) Greater anterior insula activation during anticipation of food images in women recovered from anorexia nervosa versus controls. Psychiatry Res, 214:132-141.

O'Doherty J, Critchley H, Deichmann R, Dolan RJ (2003) Dissociating valence of outcome from behavioral control in human orbital and ventral prefrontal cortices. J Neurosci, 23:7931-7939.

Ogawa H (1994) Gustatory cortex of primates: anatomy and physiology. Neurosci Res, 20:1-13.

Oudijn MS, Storosum JG, Nelis E, Denys D (2013) Is deep brain stimulation a treatment option for anorexia nervosa? BMC Psychiatry, 13:277.

Palazidou E, Robinson P, Lishman WA (1990) Neuroradiological and neuropsychological assessment in anorexia nervosa. Psychol Med, 20:521-527.

Panizzon MS, Fennema-Notestine C, Eyler LT, Jernigan TL, Prom-Wormley E, Neale M (2009) Distinct genetic influences on cortical surface area and cortical thickness. Cereb Cortex, 19:2728-2735.

Peciña S, Smith KS (2010) Hedonic and motivational roles of opioids in food reward: implications for overeating disorders. Pharmacol Biochem Behav, 97:34-46.

Perçinel I, Bilaç Ö, Köse S, Özbaran B (2015). Anoreksiya nervozalı çocuk ve ergenlerde sosyal biliş. Psikiyatride Güncel Yaklaşımlar, 7:178-89.

Petrovich GD (2013) Forebrain networks and the control of feeding by environmental learned cues. Physiol Behav, 121:10-18.

Pieters GL, de Bruijn ER, Maas Y, Hulstijn W, Vandereycken W, Peuskens J et al. (2007) Action monitoring and perfectionism in anorexia nervosa. Brain Cogn, 63:42-50.

Prince AC, Brooks SJ, Stahl D, Treasure J (2009) Systematic review and meta-analysis of the baseline concentrations and physiologic responses of gut hormones to food in eating disorders. Am J Clin Nutr, 89:755-765.

Pritchard TC, Schwartz GJ, Scott TR (2007) Taste in the medial orbitofrontal cortex of the macaque. Ann N Y Acad Sci, 1121:121135.

Renwick B, Musiat P, Lose A, DeJong H, Broadbent $H$, Kenyon M (2015) Neuro-and social-cognitive clustering highlights distinct profiles in adults with anorexia nervosa. Int J Eat Disord, 48:26-34.

Roberts ME, Tchanturia K, Stahl D, Southgate L, Treasure J (2007) A systematic review and meta-analysis of set-shifting ability in eating disorders. Psychol Med, 37:1075-1084.

Roberts ME, Tchanturia K, Treasure JL (2010) Exploring the neurocognitive signature of poor set-shifting in anorexia and bulimia nervosa. J Psychiatr Res, 44:964-970.

Robbins TW, Gillan CM, Smith DG, de Wit S, Ersche KD (2012) Neurocognitive endophenotypes of impulsivity and compulsivity: towards dimensional psychiatry. Trends Cogn Sci, 16:81-91.

Robinson ESJ, Eagle DM, Economidou D, Theobald DEH, Mar AC, Murphy ER et al. (2009) Behavioural characterisation of high impulsivity on the 5-choice serial reaction time task: specific deficits in 'waiting'versus 'stopping'. Behav Brain Res, 196:310316.

Rolls ET, Critchley HD, Verhagen JV, Kadohisa M (2010) The representation of information about taste and odor in the orbitofrontal cortex. Chemosens Percept, 3:6-33.

Roubos EW, Dahmen M, Kozicz T, Xu L (2012) Leptin and the hypothalamo-pituitary-adrenal stress axis. Gen Comp Endocrinol, 177:28-36. 
Sallet J, Mars R, Quilodran R, Procyk E, Petrides M, Rushworth M (2011) Neuroanatomical basis of motivational and cognitive control: a focus on the medial and lateral prefrontal cortex. In Neural Basis of Motivational and Cognitive Control. (Eds RB Mars, J Sallet, MSF Rushworth, N Yeung):5-20. London, MIT Press.

Sanders N, Smeets PA, van Elburg AA, Danner UN, van Meer F, Hoek HW (2015) Altered food-cue processing in chronically ill and recovered women with anorexia nervosa. Front Behav Neurosci, 9:46.

Santana N, Bortolozzi A, Serrats J, Mengod G, Artigas F (2004) Expression of serotonin1A and serotonin2A receptors in pyramidal and GABAergic neurons of the rat prefrontal cortex. Cereb Cortex, 14:1100-1109.

Sato Y, Saito N, Utsumi A, Aizawa E, Shoji T, Izumiyama M et al. (2013) Neural basis of impaired cognitive flexibility in patients with anorexia nervosa. PloS One, 8:e61108.

Schultz W (2013) Updating dopamine reward signals. Curr Opin Neurobiol, 23:229-238.

Seed JA, Dixon RA, McCluskey SE,Young AH (2000) Basal activity of the hypothalamic-pituitary-adrenal axis and cognitive function in anorexia nervosa. Eur Arch Psychiatry Clin Neurosci, 250:11-15.

Seitz J, Bühren K, von Polier GG, Heussen N, Herpertz-Dahlmann B, Konrad K (2014) Morphological changes in the brain of acutely ill and weight-recovered patients with anorexia nervosa. Z Kinder Jugendpsychiatr Psychother, 42:7-17.

Sforzo GA (1988) Opioids and exercise. Sports Med, 7:109-124.

Shepherd GM (2007) Perspectives on olfactory processing, conscious perception, and orbitofrontal cortex. Ann N Y Acad Sci, 1121:87-101.

Shott ME, Pryor TL, Yang TT, Frank GK (2016) Greater insula white matter fiber connectivity in women recovered from anorexia nervosa. Neuropsychopharmacology, 41:498-507.

Siegmund A, Golfels F, Finck C, Halisch A, Räth, D, Plag J et al. (2011) D-cycloserine does not improve but might slightly speed up the outcome of in-vivo exposure therapy in patients with severe agoraphobia and panic disorder in a randomized double blind clinical trial. J Psychiatr Res, 45:1042-1047.

Simmons JM, Ravel S, Shidara M, Richmond BJ (2007) A comparison of reward-contingent neuronal activity in monkey orbitofrontal cortex and ventral striatum. Ann N Y Acad Sci, 1121:376-394.

Slof-0p't Landt MC, Bartels M, Middeldorp CM, van Beijsterveldt CE, Slagboom PE, Boomsma DI et al. (2013) Genetic variation at the TPH2 gene influences impulsivity in addition to eating disorders. Behav Genet, 43:24-33.

Small DM, Zatorre RJ, Dagher A, Evans AC, Jones-Gotman M (2001) Changes in brain activity related to eating chocolate. Brain, 24:1720-1733.

Smitka K, Papezova H, Vondra K, Hill M, Hainer V, Nedvidkova J (2013) The role of "mixed" orexigenic and anorexigenic signals and autoantibodies reacting with appetite-regulating neuropeptides and peptides of the adipose tissue-gut-brain axis: relevance to food intake and nutritional status in patients with anorexia nervosa and bulimia nervosa. Int J Endocrinol, 2013:83145.

Southgate L, Tchanturia K, Treasure J (2008) Information processing bias in anorexia nervosa. Psychiatry Res, 160:221-227.

Sparling PB, Giuffrida A, Piomelli D, Rosskopf L, Dietrich A (2003) Exercise activates the endocannabinoid system. Neuroreport, 14:2209-2211.

Steiger H (2004) Eating disorders and the serotonin connection: state, trait and developmental effects. J Psychiatry Neurosci, 29:20-29.

Steinglass JE, Walsh BT, Stern Y (2006) Set shifting deficit in anorexia nervosa. J Int Neuropsychol Soc, 12:431-435.

Stuss DT, Levine B, Alexander MP, Hong J, Palumbo C, Hamer L (2000) Wisconsin Card Sorting Test performance in patients with focal frontal and posterior brain damage: effects of lesion location and test structure on separable cognitive processes. Neuropsychologia, 38:388-402.

Suchan B, Busch M, Schulte D, Grönermeyer D, Herpertz S, Vocks S (2010) Reduction of gray matter density in the extrastriate body area in women with anorexia nervosa. Behav Brain Res, 206: 63-67.

Suchan B, Bauser DS, Busch M, Schulte D, Grönemeyer D, Herpertz S (2013) Reduced connectivity between the left fusiform body area and the extrastriate body area in anorexia nervosa is associated with body image distortion. Behav Brain Res, 241:80-85.

Suchan, B, Vocks S, Waldorf M (2015) Alterations in activity, volume, and connectivity of body-processing brain areas in anorexia nervosa. Eur Psychol, 20:27-33.

Sullivan PF (1995) Mortality in anorexia nervosa. Am J Psychiatry, 152:1073-1074.

Swanson LW, Petrovich GD (1998) What is the amygdala? Trends Neurosci, 21:323-331.

Swayze VW, Andersen A, Arndt S, Rajarethinam R, Fleming F, Sato Y et al. (1996) Reversibility of brain tissue loss in anorexia nervosa assessed with a computerized talairach 3-D proportional grid. Psychol Med, 26:381-390.

Swayze VW, Andersen AE, Andreasen NC, Arndt S, Sato Y, Ziebell S (2003) Brain tissue volume segmentation in patients with anorexia nervosa before and after weight normalization. Int J Eat Disord, 33:33-44. 
Szmukler Gl, Andrewes D, Kingston K, Chen L, Stargatt R, Stanley R (1992) Neuropsychological impairment in anorexia nervosa: before and after refeeding. J Clin Exp Neuropsychol, 14:347-352.

Takano A, Shiga T, Kitagawa N, Koyama T, Katoh, C, Tsukamoto E et al. (2001) Abnormal neuronal network in anorexia nervosa studied with I-123-IMP SPECT. Psychiatry Res, 7:45-50.

Tchanturia K, Morris RG, Anderluh MB, Collier DA, Nikolaou V, Treasure J (2004) Set shifting in anorexia nervosa: an examination before and after weight gain, in full recovery and relationship to childhood and adult OCPD traits. J Psychiatr Res, 3:545-552.

Tchanturia K, Davies H, Roberts M, Harrison A, Nakazato M, Schmidt U et al. (2012) Poor cognitive flexibility in eating disorders: examining the evidence using the Wisconsin Card Sorting Task. PloS One, 7:e28331.

Teitelbaum P, Stellar E (1954) Recovery from the failure to eat produced by hypothalamic lesions. Science, 120:894-895.

Tenconi E, Degortes D, Clementi M, Collantoni E, Pinato C, Forzan M et al. (2016) Clinical and genetic correlates of decision making in anorexia nervosa. J Clin Exp Neuropsychol, 3:327-337.

Teng K (2011) Premenopausal osteoporosis, an overlooked consequence of anorexia nervosa. Cleve Clin J Med, 78:50-58.

Terashi M, Asakawa A, Harada T, Ushikai M, Coquerel Q, Sinno MH et al. (2011) Ghrelin reactive autoantibodies in restrictive anorexia nervosa. Nutrition, 27:407-413.

Titova OE, Hjorth $O C$, Schiöth $H B$, Brooks SJ (2013) Anorexia nervosa is linked to reduced brain structure in reward and somatosensory regions: a meta-analysis of VBM studies. BMC Psychiatry, 13:110.

Toni I, Passingham RE (1999) Prefrontal-basal ganglia pathways are involved in the learning of arbitrary visuomotor associations: a PET study. Exp Brain Res, 127:19-32.

Tsai SJ (2005) Repetitive transcranial magnetic stimulation: A possible novel therapeutic approach to eating disorders. Med Hypotheses, 65:1176-1178.

Turner H, Marshall E, Stopa L, Waller G (2015) Cognitive-behavioural therapy for outpatients with eating disorders: Effectiveness for a transdiagnostic group in a routine clinical setting. Behav Res Ther, 68:70-75.

Uher R, Brammer MJ, Murphy T, Campbell IC, Ng VW, Williams SC et al. (2003) Recovery and chronicity in anorexia nervosa: brain activity associated with differential outcomes. Biol Psychiatry, 54:934-942.

Uher R, Murphy T, Brammer MJ, Dalgleish T, Phillips ML, Ng VW et al. (2004) Medial prefrontal cortex activity associated with symptom provocation in eating disorders. Am J Psychiatry, 161:1238-1246.

Uher R, Murphy T, Friederich HC, Dalgleish T, Brammer MJ, Giampietro V et al. (2005) Functional neuroanatomy of body shape perception in healthy and eating-disordered women. Biol Psychiatry, 58:990-997.

Urgesi C, Berlucchi G, Aglioti SM (2004) Magnetic stimulation of extrastriate body area impairs visual processing of nonfacial body parts. Curr Biol, 14:2130-2134.

Van den Eynde F, Suda M, Broadbent H, Guillaume S, Eynde M, Steiger H et al. (2012) Structural magnetic resonance imaging in eating disorders: a systematic review of voxel-based morphometry studies. Eur Eat Disord Rev, 20:94-105.

Van den Eynde F, Guillaume S, Broadbent H, Campbell IC, Schmidt U (2013) Repetitive transcranial magnetic stimulation in anorexia nervosa: a pilot study. Eur Psychiatry, 28:98-101.

van Opstal AM, Westerink AM, Teeuwisse WM, van der Geest MA, van Furth EF, van der Grond J (2015) Hypothalamic BOLD response to glucose intake and hypothalamic volume are similar in anorexia nervosa and healthy control subjects. Front Neurosci, 9:159.

Vaswani M, Linda FK, Ramesh S (2003) Role of selective serotonin reuptake inhibitors in psychiatric disorders: a comprehensive review. Prog Neuropsychopharmacol Biol Psychiatry, 27:85-102.

Veling H, Aarts H, Stroebe W (2011) Fear signals inhibit impulsive behavior toward rewarding food objects. Appetite, 56:643-648.

Verhagen LA, Luijendijk MC, Korte-Bouws GA., Korte SM, Adan RA (2009) Dopamine and serotonin release in the nucleus accumbens during starvation-induced hyperactivity. Eur Neuropsychopharmacol, 19:309-316.

Via E, Zalesky A, Sánchez I, Forcano L, Harrison BJ, Pujol J et al. (2014) Disruption of brain white matter microstructure in women with anorexia nervosa. J Psychiatry Neurosci, 39:367-375.

Vicario CM (2013) Altered insula response to sweet taste processing in recovered anorexia and bulimia nervosa: a matter of disgust sensitivity? Am J Psychiatry, 170:1497.

Vocks S, Busch M., Schulte D, Grönermeyer D, Herpertz S, Suchan B (2010) Effects of body image therapy on the activation of the extrastriate body area in anorexia nervosa: an fMRI study. Psychiatry Res, 183:114-118.

Vocks S, Herpertz S, Rosenberger C, Senf W, Gizewski ER (2011) Effects of gustatory stimulation on brain activity during hunger and satiety in females with restricting-type anorexia nervosa: an fMRI study. J Psychiatr Res, 45:395-403.

Vogt BA, Nimchinsky EA, Vogt LJ, Hof PR (1995) Human cingulate cortex: surface features, flat maps, and cytoarchitecture. J Comp Neurol, 359:490-506.

Volkow ND, Baler RD (2015) NOW vs LATER brain circuits: implications for obesity and addiction. Trends Neurosci, 38:345-352. 
Wagner A, Ruf M, Braus DF, Schmidt MH (2003) Neuronal activity changes and body image distortion in anorexia nervosa. Neuroreport, 14:2193-2197.

Wagner A, Barbarich-Marsteller NC, Frank GK, Bailer UF, Wonderlich SA, Crosby RD et al. (2006) Personality traits after recovery from eating disorders: Do subtypes differ? Int J Eat Disord, 39:276-284.

Wagner A, Aizenstein H, Venkatraman VK, Fudge J, May JC, Mazurkewicz L et al. (2007) Altered reward processing in women recovered from anorexia nervosa. Am J Psychiatry, 164:1842-1849.

Wagner A, Aizenstein H, Mazurkewicz L, Fudge J, Frank GK, Putnam K et al. (2008) Altered insula response to taste stimuli in individuals recovered from restricting-type anorexia nervosa. Neuropsychopharmacology, 33:513-523.

Warren MP (2011) Endocrine manifestations of eating disorders. J Clin Endocrinol Metab, 96: 333-343.

Wierenga CE, Bischoff-Grethe A, Melrose AJ, Irvine Z, Torres L, Bailer UF et al. (2015) Hunger does not motivate reward in women remitted from anorexia nervosa. Biol Psychiatry, 77:642-652.

Williamson DA, White MA, York-Crowe E, Stewart TM (2004) Cognitive-behavioral theories of eating disorders. Behav Modif, 28:711-738

Winkler AM, Kochunov P, Fox PT, Duggirala R, Almasy L, Blangero J et al. (2009) Heritability of volume, surface area and thickness for anatomically defined cortical brain regions estimated in a large extended pedigree. Neurolmage, 47(Suppl 1):S162.

Wu H, Van Dyck-Lippens PJ, Santegoeds R, van Kuyck K, Gabriëls L, Lin G et al. (2013) Deep-brain stimulation for anorexia nervosa. World Neurosurg, 80(3): S29.e1-S29.e10.

Yau WYW, Bischoff-Grethe A, Theilmann RJ, Torres L, Wagner A, Kaye WH et al. (2013) Alterations in white matter microstructure in women recovered from anorexia nervosa. Int J Eat Disord, 46:701-708.

Yim GK, Lowy MT (1984) Opioids, feeding, and anorexias. Fed Proc, 43:2893-2897.

Young LT, Bagby RM, Cooke RG, Parker JD, Levitt AJ, Joffe RT (1995) A comparison of Tridimensional Personality Questionnaire dimensions in bipolar disorder and unipolar depression. Psychiatry Res, 58:139-143.

Zastrow A, Kaiser S, Stippich C, Walther S, Herzog W, Tchanturia, K et al. (2009) Neural correlates of impaired cognitive-behavioral flexibility in anorexia nervosa. Am J Psychiatry, 166:608-616.

Zhang HW, Li DY, Zhao J, Guan YH, Sun BM, Zuo CT (2013) Metabolic imaging of deep brain stimulation in anorexia nervosa: a 18F-FDG PET/CT study. Clin Nucl Med, 38:943-948.

Zhang D, Raichle ME (2010) Disease and the brain's dark energy. Nat Rev Neurol, 6:15-28.

Zhu Y, Hu X, Wang J, Chen J, Guo Q, Li C et al. (2012) Processing of food, body and emotional stimuli in anorexia nervosa: a systematic review and meta-analysis of functional magnetic resonance imaging studies. Eur Eat Disord Rev, 20:439-450.

Zincir SB (2014) Yeme bozukluklarında nöroendokrin ve moleküler etkileşimler. Psikiyatride Güncel Yaklaşımlar, 6:389-400.

Zipfel S, Wild B, Groß G, Friederich HC, Teufel, M., Schellberg D et al. (2014) Focal psychodynamic therapy, cognitive behavior therapy, and optimised treatment as usual in outpatients with anorexia nervosa (ANTOP study): randomised controlled trial. Lancet, 383:127-137.

Deniz Atalayer, Sabancı University, Istanbul.

Yazışma Adresi/Correspondence: Deniz Atalayer, Sabancı University Faculty of Arts and Social Sciences, Psychology Department, Istanbul, Turkey. E-mail: denizatalayer@gmail.com

Bu makale ile ilgili herhangi bir çıkar çatışması bildirilmemiş̧ir. - No conflict of interest is declared related to this article.

Geliş tarihi/Submission date: 1 Kasım/November 1, 2017 · Kabul Tarihi/Accepted: 29 Kasım/November 29, 2017 